\title{
Ramarama, Ruatahuna, Oxford, Jerusalem
}

\section{Introduction}

\section{He koorero timata}

He koorero teenei moo ooku wheako i Tipene Kura ki Ramarama, ki Ruataahuna i te Urewera, ki Hiruhaarama i Israel/Palestine, ki te Whare Waananga o Oxford hoki i te tau 1972 ki 1977. He koorero hoki teenei moo tooku tuutakihanga i eetahi taangata tae hoki raa ki a Hoani Rangihau.

I talk below about my experiences at St Stephens School at Ramarama/Bombay, in Ruataahuna, in Jerusalem in Israel Palestine and at Oxford University in the years 1972-7. It is also about meeting various people including John Rangihau.

He mea taiaawhio teenei i eetahi ahua inahoki kua hipa eetahi awa, eetahi huarahi, eetahi moana, etahi paparahi, aa, he taawhiti kee te haere i a Aotearoa ki a Ingarangi, i a Ingarangi ki a Hiruhaarama. Kia waanangahia teenei whakaaro e tika ana kia kii pea ka rere eetahi ira i Ruataahuna ki Hiruhaarama me te hokohanga mai hoki ki a Aotearoa, aa, he paku koorero naaku moo eenaa i te nuku o te tuhinga ki raro.

This is something of a circumnavigation in that roads, rivers, oceans and continents around the world are crossed and its a long way from Aotearoa to England and from there to Jerusalem, Israel and then too the return to Aotearoa. Considering this there there are some threads between Ruatahuna and Jerusalem and there is some discussion of them in the course of the writing below.

Naaku noa,

Naa Peter Cleave

Professor Peter Cleave (Wolfson College, Oxford), is a widely-published New Zealand academic, currently focusing on issues relating to contemporary as well as historical Maori development. 
Mai i eetahi waahi timata kua whiringia teetahi whakaahua o maatou ko ooku hoa ki te mahau o tooku whare ki a Ramarama i te tau 1972. Ka haangai teenei whare ki te kura o Tipene ki teeraa taha o te huarahi nui. Te rerekee hoki o eenei waahi. Ko te kanohi o tooku whare, he mea panekiritia naa e te Bougainvillia, ko te kanohi o Tipene, he mea kiwikiwi kee raa.

Out of a number of possible starting points the group photo at my house on the Bombay hills in 1972 may be a good place to start. This house was just across the road from St Stephen's School, something of a contrast as the photographs show. The photo of me and my friends on the bougainvillia draped verandah of the old house I rented from the Main family where I had built an outdoor theatre and set up a workshop-studio was a very different place to the strict, dour even, face of St Stephens School.

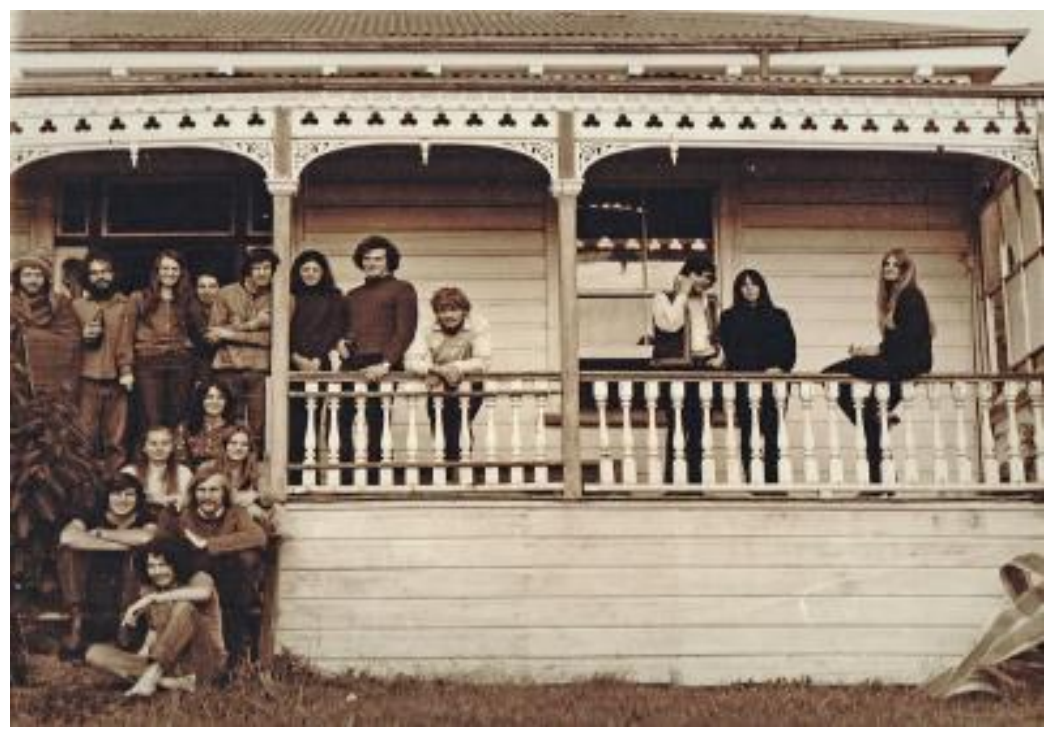

Kei te noho au i te paepae tuatahi ki te taha maaui. I am sitting on the left on the first step. 


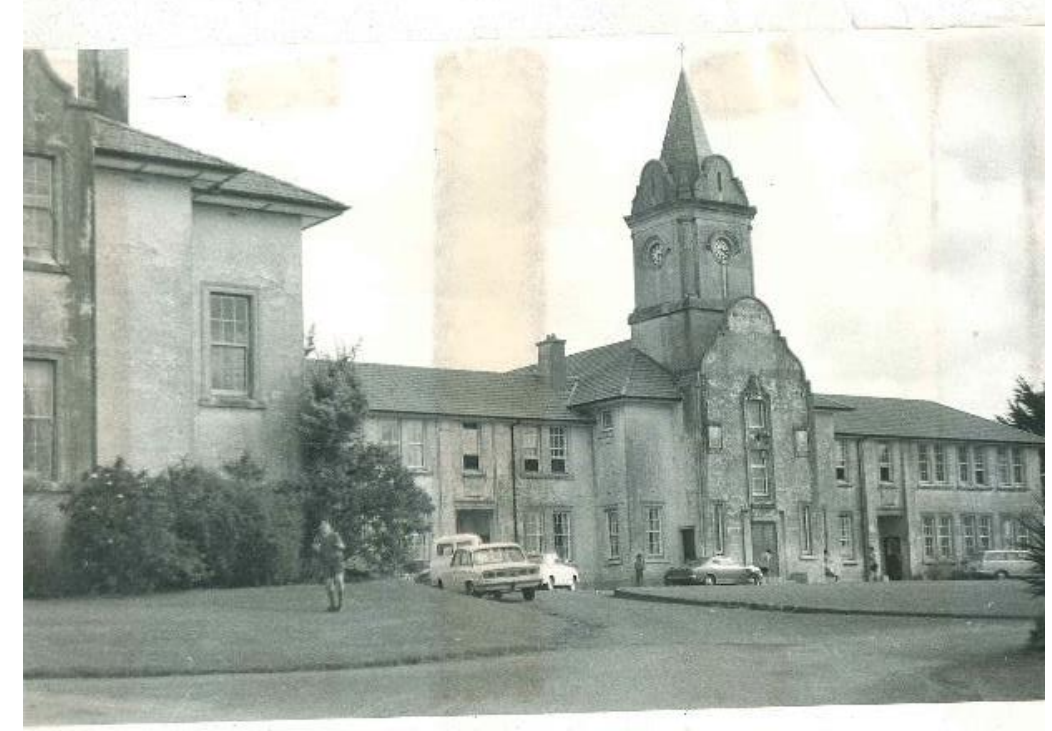

Tipene Kura i 1972. He whakaahua na Peter Boyd i taku tuhinga moo Tipene Kura (1976).

St Stephens in 1972. A photograph by Peter Boyd. From my thesis on St Stephens (1976).

I a au e noho ana ki Ramarama ka maarena au, aa, ka haere maaua ko tooku hoa, a Leonie ki a Waikaremoana whakataa ai. Ko teenaa tooku waa tuatahi ki te kite i a Ruataahuna inahoki kai te huarahi ki Waikaremoana a Ruaataahuna. Ka whakaaro $\mathrm{au}$, he waa motuhake ki roo tonu i te ngaahere teenei waahi...ko te huarahi, he mea pikopiko, he whaaiti rawa, aa, he nui te puehu. Ko te taenga ki Ruataahuna, he waa teenaa moo teetahi kaputii pai ki te toa o Rimmer. Ka haangai teenaa toa ki teetahi huarahi ki te taha,aa, ka tuu eetahi whare kaawanatanga ki reira, he hoiho. he waka taawhito hoki i teetahi waahi waatea e tata anaa ki teenaa huarahi. Koa kee a Alf Rimmer ki te koorero ki a maaua.

While I lived at Ramarama I married and myself and my wife Leonie honeymooned in Waikaremoana. This was my first time 
to Ruatahuna as it lay on the road to Waikaremoand. I thought it was a special kind of a place being right in the middle of the bush....we did not turn off the road which was a challenge, narrow, metal and winding unremittingly through clouds of dust. Arrival at Ruatahuna allowed a welcome cup of tea at Rimmer's General Store set back up from the road opposite a side road of state houses and a paddock with horses and disused cars where Alf Rimmer as I later got to know him as, was glad to see us and chatted away.

I mua o teenei i teetahi raa ka hiikoi au ki teeraa taha o te huarahi i a Ramarama kia maatau ai au hai kuramahita taapere. He mea pai rawa, ka pooheehee pea au, i te mahi miraka kau moo te whanau Main.

One day I walked across the road at Ramarama and offered my services as a drama teacher, this besting, or so I thought, milking cows for the Mains and others for money.

Ka noho maaua ko Tio Lewis, te Tumuaki o te kura, aa, ka koorero maaua moo te hutupooro. Ko au, he rima tau ooku ki te Tekaumarima Tuatahi o Manurewa. Kei roo tonu a Manurewa $i$ te rohe o Counties wheenaa i a Ramarama, noo reira he rahi ooku wa taakaro ki a Tipene Kura. Ka whakaaro au moo te haerenga maa runga paahi, too maatou naa hinganga $i$ raro $i$ teetahi kapa o Tipene, nui rawa, pai rawa hoki i a maatou. 


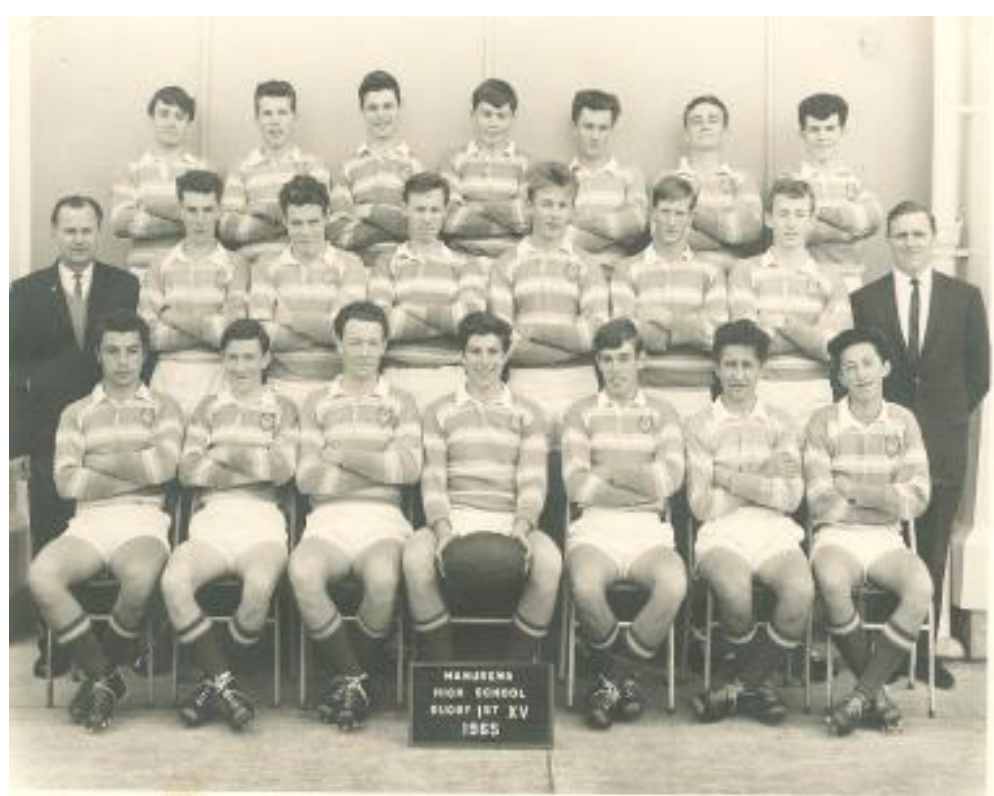

Te kapa hutupooro o te kura tuarua o Manurewa. Ko au te Tumuaki,

The Manurewa High School First Fifteen. I am the Captain.

I sat talking to Joe Lewis, the Headmaster, about rugby. Having played in the first fifteen at Manurewa High, St Stehens, for my entire five years of schooling there I knew St Stephens, part of the Counties rugby area, like Manurewa, well. The bus trip to Ramarama from Manurewa, going up the drive and getting whacked by a team regularly bigger and better than us was familiar.

Kua tuu au hai kura maahita taapere moo eetahi marama. Ki tua o teenaa ka paatai mai a Tio maaku hai maahita taakaro hoki. Ko teetahi aapitihanga ko te mahi maahita whare noo reira ka nuku maaua ko tooku hoa ki te whare i kiia ai ko Pomare noho ai.

Having got a position, if that it might be called, as a part time drama teacher for a few months Joe Lewis then offered me the job of teaching Physical Education. With that came the idea 
of actually crossing the road to live as a housemaster in Pomare House.

I te taha o teenei ko te tuutakitanga ki teetahi roopu aakonga mai i a Ruataahuna. Kei roto o taaku hui taapere eenei. Ka paatai teetahi o teenei roopu maaku e hari i te roopu aakonga Tuuhoe ki te whakatuuwheratanga o te wharenui, Te Tira Hou ki a Taamaki Maakau Rau. I reira ka kite au moo te waa tuatahi i a Hoani Rangihau. Mai taawhiti.

Along with this was the introduction to a group of Tuhoe students from Ruatahuna some of whom were in the drama group. One of them asked me to take them to the opening of the Tira Hou marae in Panmure an urban Tuhoe marae and this I did and there I first saw John Rangihau. At a distance. 


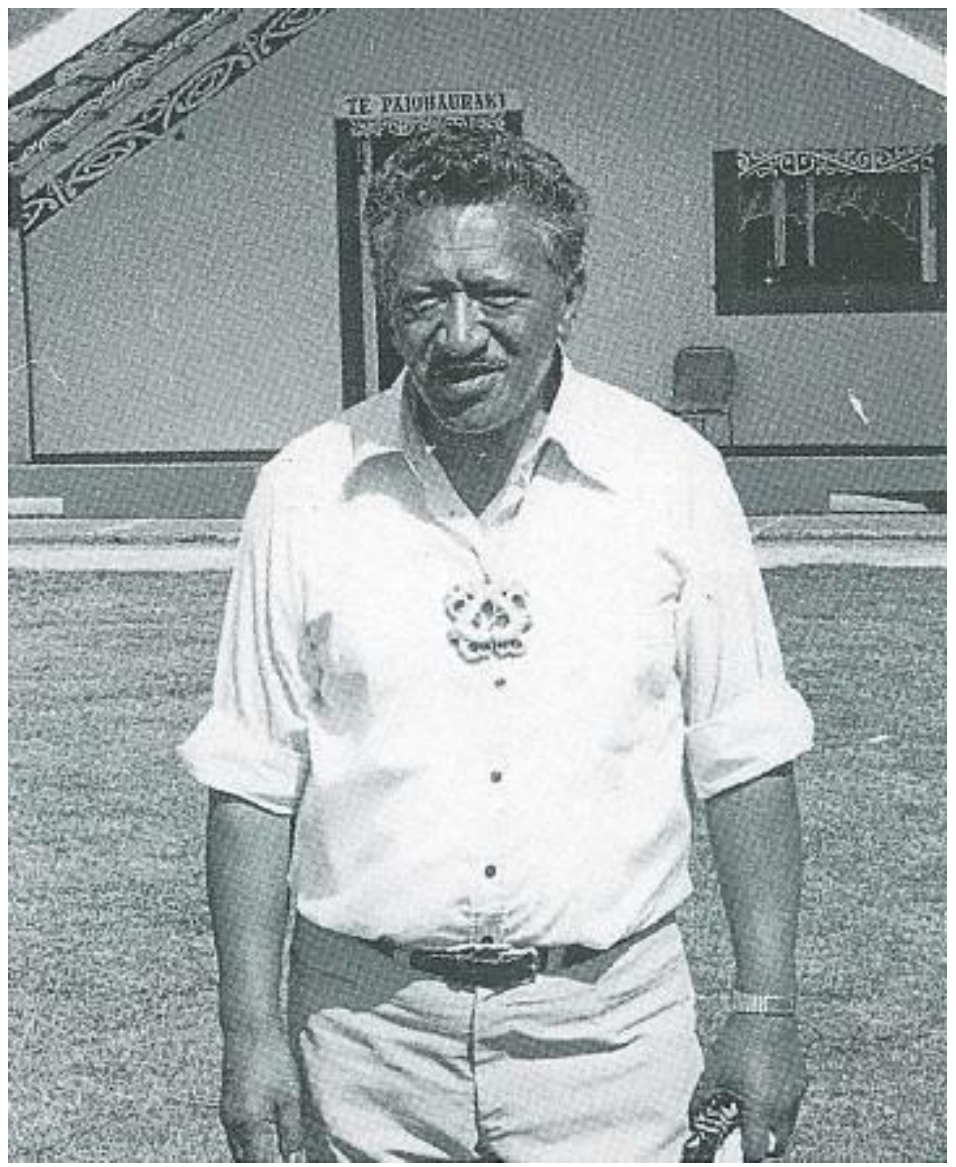

Hoani Rangihau ki Te Pae o Hauraki marae.

Mai i Te Mauri Pakeake naa Greenwood me Wilson (2006:72)

John Rangihau at Te Pae o Hauraki marae.

From Te Mauri Pakeaka by Greenwood and Wilson (2006:72)

Ko te whakawhiti o te huarahi, he haerenga i teetahi aahua ngaakau, hinengaro hoki ki teetahi anoo, i teetahi tauira mahi ki teetahi anoo, i teetahi tauira ora ki teetahi anoo hoki. Ka 
whakawhiti au hai maahita whare, kia uru ai hoki au ki teetahi hapori.

Crossing the road meant crossing with ego, with work patterns, with life habits. I crossed to become a housemaster and also to be part of another community.

Ko teetahi take i teenei hapori hou ki a au ko te whakaaro moo te hapori whaanui, kaaore moo te tangata noa iho. Ko te whakaaro o te whaanau hai mea e toro atu ki te kura, ki te iwi whaanui, te hapuu me te iwi, me kii, he mea rerekee noa teenei ki a au.

One point about this new community to me was that there was another community beyond the individual. The way the family reached to the tribal, to a wider community, this was quite different to me.

Ko te whakaaro moo te mea e kiia nei ko 'social work', te mahi toko i te ora, he mea kaaore kau raa i meatia ai e au $i$ mua.

As for the thought of social work, of support work for others, that was something I had not considered at all.

He nukuhanga teenei $\mathrm{i}$ te ao toi ki te ao o ngaa taangata e whai tikanga ana. He aahua orite pea eenei mea. he mea tuia anootia pea. I a au e ako ana i te kaupapa e kiia nei ko Anthropology ka awhina hoki au i te mahi taapere moo Hatupatu me Kurungaituku. Ko teetahi pepa moo teenei ko taaku tuhinga tuatahi kia taangia (Ako 1973).

One reason was that I was changing from being an artist, an isolate with a specific view to being an anthropologist, another kind of isolate perhaps, trying to find the generally shared views of a community. These entwined, if indeed they were actually all that different so that I was doing the drama work for a play to go into the school concert party, Hapupatu and the birdwoman, and at the same time I was doing Masters papers in Social Anthroploogy at Auckland University. My first published paper was, in fact, about this play and this appeared in the journal Ako (1973). 
He roa kee te haerenga ki Tamaki Makau Rau me the hokihangamai, he uaua hoki. Whaa tekau maero te tawhiti, aa, whaa tekau maa rima miniti pea te roa ki roo waka. He mea uaua kia whakaarongia ngaa mea katoa o te kura engari ka haere tonu au i muri i eetahi raa roa ki roo ruma ako me te mahi tiaki i te whare o te kura. He uaua hoki moo ooku kaiako ki te Whare Waananga o Taamaki Maakau Rau!

The trip to and from Auckland was long and difficult to do from St Stephens on the Bombay Hills to Auckland, some forty miles taking about three quarters of an hour with all that was happening at the school but I boxed on and the lecturers did so as well with a tired and worn out student showing up after a day's teaching and housemastering. 


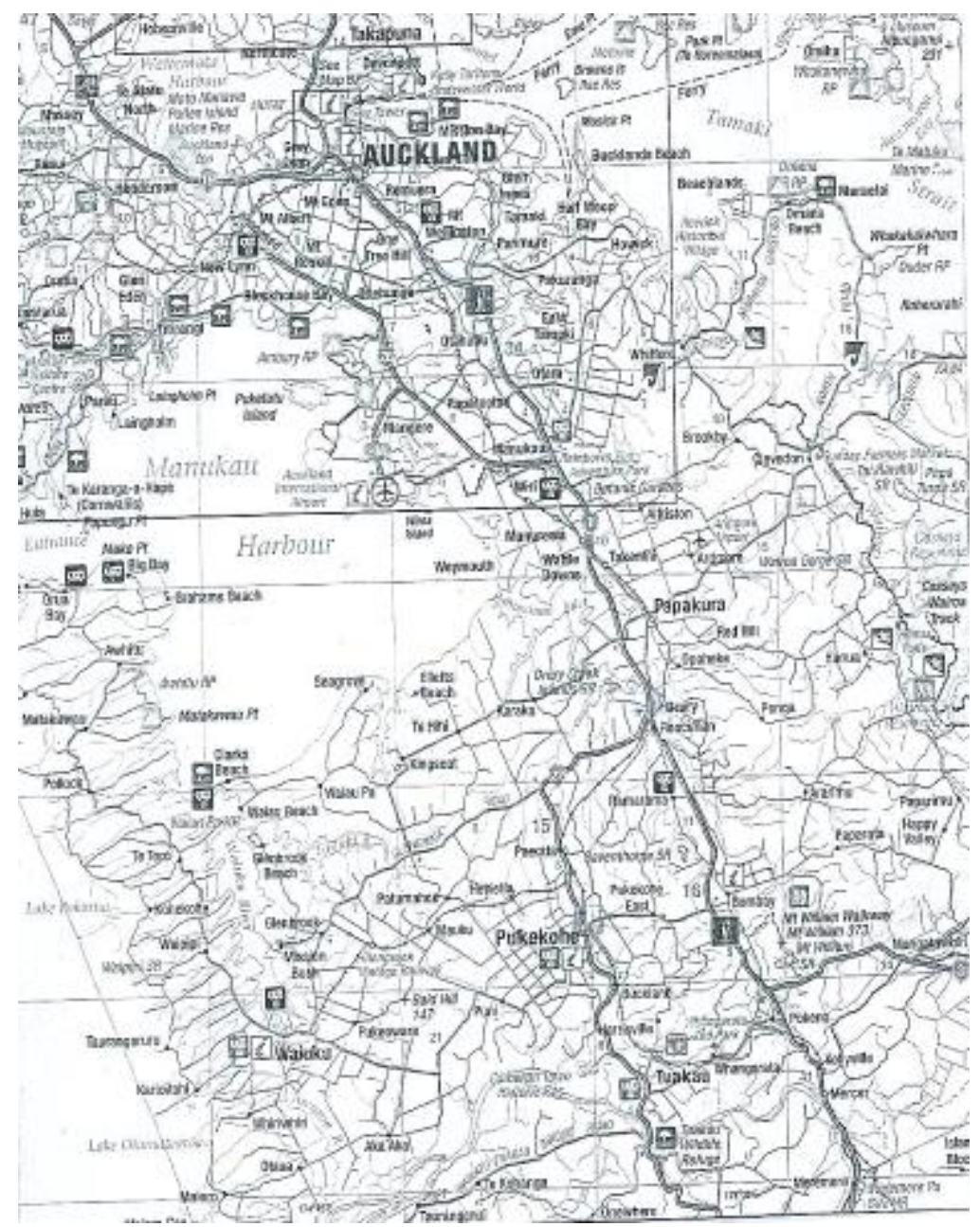

Taamaki Maakau Rau ki te Tonga

South Auckland

from Hema Maps, New Zealand Handy Atlas 4th Edition

Ka haere tonu te tau 1973 ki toona whakaotinga. Kua riro $\mathrm{i}$ a au he tohu tuatahi mo aaku pepa i mua i te mahi tuhi pukapuka, aa, ka haramai hoki teetahi tamaiti. Kaaore i te pai 
ngaa ruma maahita moo eenaa momo mea noo reira ka nuku maaua ki a Taamaki Maakau Rau.

The year of 1973 rolled along until the end. I had won a first class honours in Anthropology at the papers point with a thesis to come and I was also a father to be. The housemasters quarters were not really ideal for a baby so we moved to Auckland.

He whakaaro nooku i teenaa waa kua tuia eetahi mea i tooku hinengaro.

There was a sense for me that intellectually things had come together.

I mua o eenei mea kua taea e au he B A i te kaupapa Anthropology i a au e mahi ana ki te Whare Taapere o te Mercury, e mahi raanei $i$ te ngaahere i a au e topa maanuka ana, e mahi kee raanei i ngaa waka panana me eenaa momo mea. I teetahi tau ka mahi au i taku rakuraku i tetahi roopu waiata ki te Waikato.

While I had taken a Bachelor of Arts degree in Anthropology that had happened in between running the front of the house at the Mercury Theatre, jaunts on banana boats, cutting scrub on Waiheke Island, playing guitar in a country band in the Waikato and so on.

Ko ngaa kaupapa o te whare waananga i whaia ai e au i teenaa waa he mea kau noa eenaa kaaore he whakaaro hoohonu nooku. Ka patipati au moo ngaa whakaaenga kia maatau ai au i ngaa whakataetae, aa, ka taea eenaa e au ko teenaa, teenaa.

I had not actually noticed the subject except as a way to get through a Bachelors. In those days you could 'crawl for terms' in September in order to sit papers in November and this I regularly did.

I teenei waa kua paanui whaanui au, aa, kua tuutaki au i a Tipene Webster me Max Rimoldi, aa, he taangata nui eenaa ki a au. I teenaa waa hoki i uru ai au ki te wao o Tipena Kura, ngaa whakaaro o ngaa aakonga Tuuhoe me eetahi atu aakonga, 
aa, he whakaaro nooku hoki i teenaa waa moo ngaa reo o te ao tae noa ki te reo rangatira.

Now I had done some serious reading, met Steve Webster along with Max Rimoldi, scholars who made a great impression on me, while at the same time getting into the life of the school at St Stephens, the ideas of the Tuhoe and other students and thinking about language, especially, Te Reo.

Kaaore anoo kia tae au ki a Oxford te kaainga o Anthropology ki a eetahi, me kii, aa, kaaore anoo au kia noho moo teetahi waa roa ki a Ruataahuna engari ka whakaaro au moo nga waahi peenei i a au e taraiwa ana ki Taamaki Maakau Rau, aa, i a au e hiikoi ana maa te tai i a Kariotahi ki Orua ki te tai hauaauru, he rua, toru raa te waa moo teenei...he ao moo te tuutakihanga o eetahi whakaaro rerekee...ko te haerehanga ki teenaa waahi, teenaa, he toronga pea, he mea aapiti...

I was not at Oxford, the home, for some, of Anthropology yet and nor had I spent anreal time in Ruatahuna but I thought about these kinds of places as I drove back and forth to Auckland or walked on the West Coast from Kariotahi to Orua Bay, a two to three day affair....it was a world where ideas from different places met...going to the actual places was an extension, a kind of a bonus...

I te tau 1974 ka whakaako au ki te Whare Waananga o Taamaki Maakau Rau, aa, ka paatai mai a Tipene Webster, tooku rangatira moo taaku tuhinga, kia haere au ki teetahi hui ki te Tari Maaori. I teenaa hui ka tuutaki au i a Hoani Rangihau, kanohi ki kanohi moo te waa tuatahi.

In 1974 I was tutoring in Auckland and my thesis supervisor, Steve Webster, suggested I go to a meeting in the Maori Studies department with people from the University of Waikato and elsewhere. And who whould be there and who should I finally meet but John Rangihau?

Ko Hoani, he mea koroua, he mea rangatira hoki i teenaa waa. Ki a au wheenaa ia i a Bruce Biggs me Keith Sinclair. I te nuinga o te waa ka huna au i a raataou inahoki he rahi rawa atu eetahi o aaku mahi. He maatua koa maaua i a Te Raawhiti 
inaaianei, aa, he mahi anoo teenaa. Ka noho au i tooku anoo wao.

John was one of a set of senior figures at the time such as Bruce Biggs and Keith Sinclair. Mostly I avoided them simply because life was hard enough with teaching, buying houses, moving from Bombay to Auckland and we were proud parents of Te Raawhiti who kept us busy. I had never been part of an elite students group or anything like, tending to live in my own bubble. Simply, I did not have time to socialise wih anyone much including other students of Anthropology or staff. We were now the proud parents of Te Raawhiti. I lived in my own space and time.

Aa, aapiti i teenei, ka huri kee raa raatou i a au. Ka paku korero au i te reo i eenaa raa, aa, ka rangahau hoki au i taaku tuhinga moo Tipene Kura, aa, ko teetahi mea he peenaa au i teetahi kaaore kau ki reira... Ka noho au ki te ao tuuturu, i roo tonu i te reo me oona aahua, aa, ko raatou kei waho pea raatou i teenaa ao nooku. He mea wao pea; maa raatou too raatou anoo wao, maaku tooku. He rongo i puta mai ki muri, i tooku wa ki Oxford, engari mai i eetahi take kee pea.

And also they avoided me. I spoke Te Reo to a point in those days and I was busy researching the thesis on St Stephens but it was as though I was not there...I used to think that they lived in an area outside the real world and I did not get it. It was a question of dimensions; they lived in one and I in another, a feeling I got later at Oxford with other scholars and, possibly, on other grounds.

Ko teenei rongo hai mea noho motuhake au i eetahi taangata, mai i eetahi take pea. Ko teetahi pea ko te mahi o te tangata whai tikanga he mea whakarongo kaaore he mea whakauru, whakaraweke pea i te waa kaainga. Kaaore he whakaaro tika teenei ki a au. Pai rawa maa te tangata e tuu ake kia kitea ai oona aahuatanga.

This sense of being apart might have been for several reasons. One perhaps was that anthropologists were meant to be in a bubble of silence and not to affect or disrupt the local 
life. That never worked it seemed to me. You were better to say your bit and play your part when asked.

Aapiti ki teenei kua haramai au i te taha o Maaori i te kura i te papa taakaro hutupooro. Naa teenaa he whakaaro rerekee kia taawhiti ai. I tooku kura ki a Manurewa i reira ngaa whanaunga noo Hoani Rangihau mai i a Te Waimana.

Also in my own particular case I had been around Maori all my life mostly at school and on the rugby field. So the idea of a distanced or silent, detached relationship was a strange one to me. I had gone all through school in Manurewa with forms where John Rangihau's relations from Waimana were also.

Teeraa pea naa te aahua o te tangata eenei momo mea. He tangata koa ki te pahopaho au pea.

Perhaps this is a matter of temperament. Perhaps I just like to broadcast.

Ka kite a John Rangihau i teenei, aa, ka mea mai, 'He pai koe ki te ao paaho'. I ai ki a ia moo te ao toorangapuu teenei. Ki a au he mea kata teenaa engari he whakaaro anoo. Ko te whakatinanatanga o te whakaaro nei ko eenei pea; ka titiro whakamuri au ki eenei tau rua tekau, i a au e paaho ana $i$ te reo Maaori atu i teetahi teihana irirangi reo Maaori he ono ra $i$ te whitu ia wiki, ia wiki, me aaku mahi iti i te ao toorangapuu peenaa i tooku tuu moo Reipa ki te Tuuru o Waikato i 1984 , tooku tuu raanei moo Mana i te tau 2011.

John noted this about me way back then in 1976 or so saying that I was 'good at media'. He thought it bespoke a political calling which I thought a bit of a joke but interesting. How that worked out is that in 2016 I look back on twenty years or so speaking Maori six days a week on the Maori radio with a lifetime of dabbling in politics, standing in marginal seats for Labour, standing for Mana in utterly unwinnable situations and that type of thing.

He tika taa te Rangihau i koonei peenei i te nuinga o aana koorero i ngaa waa katoa.

John, as usual, got it mainly right in his analysis. 
I te nuinga o te waa he rahi kee aaku mahi i a au e haere, hoki raanei i a Tipene ki a Taamaki Maakau Rau moo aaku pepa $\mathrm{i}$ te tau 1973. I te tau $1974 \mathrm{ka}$ noho maatou ki a Taamaki Maakau Rau engari e kore e roa ka nuku anoo maatou ki a Kirikiriroa. I Taamaki Maakau Rau au moo eetahi marama e waru, me kii, inahoki e mahi tonu au i a Tipene i ngaa maarama tuatahi o te tau.

Mostly though, five years earlier, I was busy rushing back and forth from St Stephens doing my papers in 1973, settling into Auckland in early 1974 only to have to pack up almost immediately, mentally at least, as I knew I had a job at Waikato mid 1974 and then left in the last months of the year. Having arrived in Auckland in March-April I had spent the in grand total of around eight months in Auckland the first one or two going back and forth to teach at St Stephens.

Ka taahuringia au ki teetahi tuuranga ki te Whare Wananga o Waikato, aa, Ka tuutaki pai au, aa. ka tiimata au ki reira i te tiimatatanga o te tau 1975. Kua timata noa te tau ka haramai a Brenda Fairlie ki too maatou whare noho ai me toona hoa a Pera Tahi i a Mataatua Pa, Ruataahuna.

So starting at the beginning of 1975 I lectured at the University of Waikato in the newly formed Maori Department. I was the second appointee and my job was to teach culture. The year had hardly started when Brenda Fairlie came to live witb us along with Aperahama Tahi of Maataatua Paa Ruataahuna.

Ka timata peenei eetahi tau i a au e haere ana ki te Urewera $i$ te taha o Pera maa ki te awhina i te mahi kaamura i eetahi whare peenaa i Te Whai a te Motu, Tuuhoe Pootiki ki Ohaaua ki re Rangi raanei. I eetahi waa ka hiikoi noa maatou ko tooku whanau ki te Urewera, mai, me kii i a Ruataahuna ki a Ruaatoki, i a Ruataahuna ki a Te Waimana maa Maungapoohutu raanei. I eetahi o eenei hiikoitanga ka haramai hoki a Tangiora Rangihau teetahi tamaahine naa John.

So began a couple of years of going regularly to the Urewera with Pera and others to help rebuild or refit meeting houses at Ohaauakiterangi or Te Whai a te Motu in Ruataahuna itself or 
just to go into te Urewera for long walks from say, Ruataahuna to Ruaatoki or Ruataahuna to Te Waimana via Maungapoohatu. On some of these walks we were acompanied by Tangiora Rangihau, John's daughter

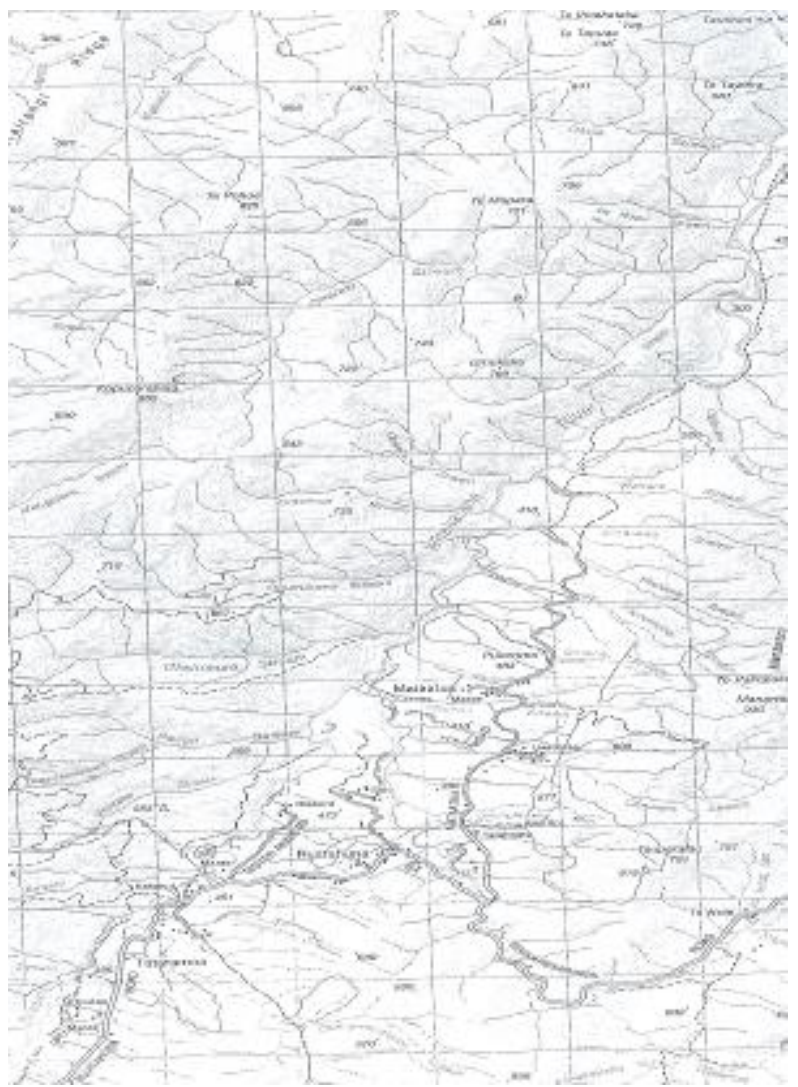

Te riu o Ruataahuna. Kai te maahere a Mataatua Paa. Kai waho noa o te taha matau ki runga rawa a Ohaaua ki te Rangi i te taha o te awa Whakataane.

The Ruatahuna area. Mataatua Paa is in the map and Ohaaua ki te Rangi is just off the map top right alongside the Whakataane river.

Land Information NZ Topo 50 BG 39 
Naa te mea kua matatau au moo ngaa mea wheenaa i te rakuraku, te puu me nga mea kaamura ko eenaa te kaupapa o ooku waa ki te Urewera. Ko te mea i koa kee au ki te koorero Maaori ko teenaa teetahi mea aapiti ahakoa he mea tino rerekee ki eetahi!

Because I could handle things like guitars, guns, hammers and saws they were the basis for me being in the Urewera. The fact that I liked to speak the language of the area was really an interesting oddity for all concerned including me.

Ka tata au ki te moohio i ngaa huarahi o te Urewera, aa, i a au e hiikoikoi ana he rahi te reo Maori i koorerongia ai inahoki ko teenaa te reo o te ara, te whare ngaahere me te marae tonu o Ohaaua ki te Rangi. Ko teenaa teetahi toopito mooku i waaenganui i a Ruaatoki me Ruataahuna, he paa taawhito o Te Kooti, taawhiti rawa i te ao ki waho o te Urewra.

I got to know the Urewera, especially the tracks quite well and in doing so spoke a lot of Maori as that was the language of the track, the hut and of the marae in the sky, Ohaaua ki te rangi itself, which became a kind of a hub for me. This was Te Kooti's old retreat, between Ruatahuna and Ruatoki, away from it all.

Ka haere au i teena waa i te Rauna Tuuhoe tae hoki ki te Ahurei me te haerehangamai o Tui Teka me Missy ki a Kirikiriroa. I eenaa waa ka haere maaua tahi ko Pera ki te Te Rapa Tavern maatakitaki ai i a Tui. Mai i a Huiarau a Tui Teka ki teraa taha o te whaarua o Ruataahuna i a Mataatua Paa.

I was experiencing, I suppose, what might be called The Tuhoe Round. This included the Festival which had just started and things like Tui and Missy. When Tui Teka and his entourage including Missy from the Coast came to town in Hamilton Pera and I would go to the tavern where they were playing, this was the day of the showband and Tui was, of course from Ruatahuna, from across the valley from Mataatua $\mathrm{Pa}$ near Huiarau School. 
Ko Hoani Rangihau, i teenaa waa kei te Centre for Maori Stdies ia i te taha o Te Kootahitanga Mahuta. Ko au ka noho au ki teeraa taha o te hooro ki te Tari Maaori.

John Rangihau at that time was in the Centre for Maori Studies along with Bob Mahuta and I was across the hall in Maori Studies.

I te tau 1976 ka nuku a Hoani me toona whaanau ki teetahi whare tata mai ki tooku. Ka whaanau mai taa maaua tamaahine, Mela i teenaa waa, aa, ka tapa a Hoani i a ia ko Rangipapa.

In 1976 John and his family moved to a house just along the road from me. My daughter Mela was born at that time and John gave her the name Rangipapa.

Kua hiikoi tonu au i teenei huarahi mai i teenaa waa. Ia tau, ia tau ka haere au ki te Urewera. I eetahi waa ka mahi au moo eetahi roopu e haangai ana ki a Tuuhoe peenaa i a Te Ata Hou, moo te Tari Matauranga i te Tuuhoe Schools Project raanei.

This is a connection I have maintained through to 2016. Most years I go somewhere in the Urewera sometimes working for Tuhoe organisations such as Te Ata Hou, a PTE which worked there for many years or for the Ministry of Education in the Tuhoe Schools Project of the 1990s.

Aapiti atu i eenei mea ko ngaa hui. I te matenga o too Hoani hoa wahine, a Wena i reira au i te taha o te whaanau pani ki a te Tira Hou, aa, ki muri ki Mataatua Paa Rotorua. I te Whare Waananga o Waikato ka haere maatou, ia tau, ia tau ki runga marae moo te katoa o teetahi wiki. Ka haramai hoki a Hoani Rangihau ahakoa no te tari rangahau kaaore noo te tari ako ia. I te nuinga o ngaa waa ka haere maatou ki eetahi marae o Tuuhoe.

And then there were the hui. When John's wife Wena died I was with the whanau pani at the Tira Hou, firstly and then at Mataatua $\mathrm{Pa}$ Rotorua. There was also the fact that in the Department of Maori at Waikato the annual trip was a big event and we, John included even though he was from the Centre for 
Maori Studies across the hall would go away for a week, usually but not always to Tuhoe marae.

Ka tito au i eetahi waiata peenaa i a Ngaa Whare, a, ka waiatatia tonutia eenei i teenei ra ki tooku moohio. Moo te wharenui o Te Whai o te Motu me te wharekai, Tuuhoe Potiki teenaa waiata engari ka whakarerekeetia nga ingoa moo teenaa marae, teenaa.

I wrote songs such as Nga whare for our trips. Nga whare was written for the wharenui and the whakekai at Mataatua Paa Ruatahuna, Te Whai a te motu and Tuhoe potiki. Later people would subsitute names of whare wherever they happened to be going. The song is still performed and is in fact how I am remembered in the Department of Maori at Waikato.

Ka tuhi au, aa, ko Hoani raaua ko Tangiora ka whakarunga pewa raatou i a au. I te tau 1976 ko te mahi tuhi ko teenaa moo Tipene Kura. Ki tua o teenaa ko Wai Maori, Wai Tai, he kohinga koorero i roto i te reo. I te taha o eenei ko Pukapuka Kupu Aahua o te Reo Maaori i a Oxford.

As always I was writing and John who was not a writer was looking on with bemusement as was Tangiora his daughter. In 1976 it was the thesis on St Stephens. Then it was Wai Maori Wai Tai, a collection of writings in Maori. At the same time I was contributing to the Oxford Picture Dictionary of Maori, these through 1976-7.

I teenaa waa ka ako au i teetahi akoranga moo te ao toorangapu Maaori. Kaaore a Hoani i whakaae ki teenaa- ki a ia ka whai au i teetahi tirohanga Paakehaa. Ko teenei ko te kaupapa o taaku mahi ki a Oxford, aa, te kaupapa o teetahi tuhinga ki te JPS hoki.

Also I was teaching a course in Maori Politics which John disagreed with- he thought that Maori politics was a Pakeha misnomer or invention, that Maori thought of politics in a different way to Europeans. That course became the basis for my Oxford Doctorate and a paper published in the JPS in 1983 that became a standard reading text in Maori Studies in several universities. 


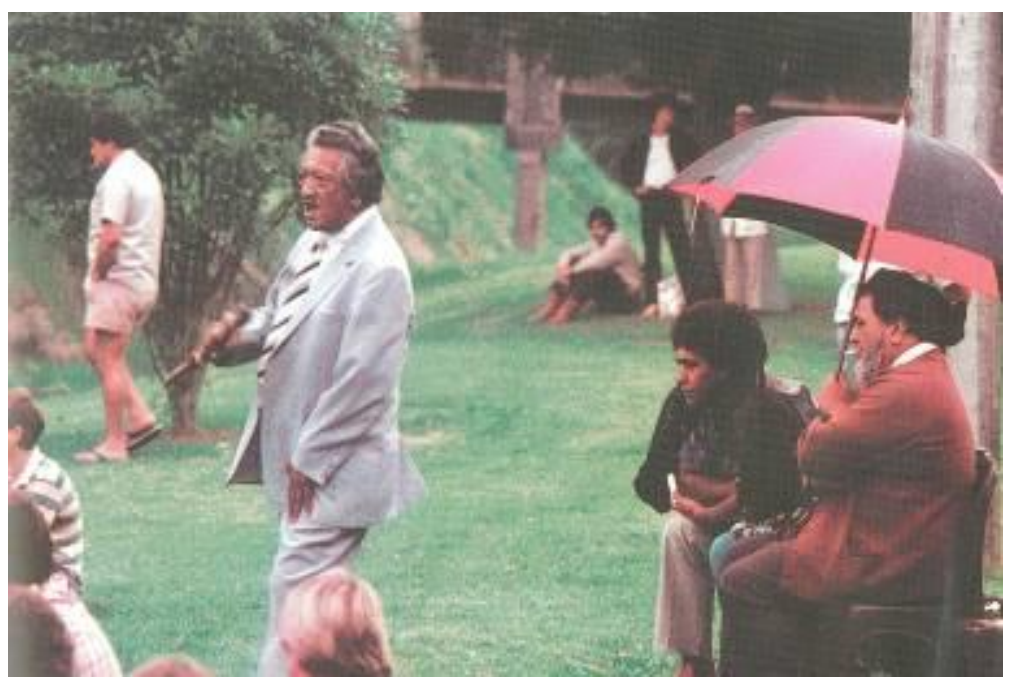

Mai i Te Mauri Pakeaka naa Janinka Greenwood me Arnold Manaaki Wilson (2006: 82) teenei whakaahua.

This photograph is from byTe Mauri Pakeaka by Janinka Greenwood and Arnold Manaaki Wilson.

Engari ka koorero hoki au. Ka koa au ki te whaikoorero, aa, ka karangahia au ki te tuu ki runga marae i eetahi waa atu ki teenei waa. Ko taaku mahi inaianei ki te reo irirangi Maaori kai te peenaa i te whaikoorero $i$ eetahi ahua. Kaaore au i te moohio naa te aha teenei. I eenaa tau 1975-7 ka koorero maaua ko Te Kootahitanga Mahuta mo eenei take inahoki kua tuhi ia moo whaikoorero, aa, he tangata tino matatau ia moo teenei kaupapa.

But I was talking as well. I got interested and got called on to deliver whaikoorero in 1975-7 and have kept at it for the rest of my life, my job on the Maori radio speaking te reo being a very light form of formal speech. For some reason that became my thing. Back in 1975-7 Bob Mahuta had done a thesis on it and we would talk long about speechmaking.

Ko tooku koa moo whaikoorero, he mea nukunuku i a au ki te ako i te reo. Aapiti i eenaa ka ako au i a au e noho ana $i$ te 
taha o Pera Tahi i a maaua e maatakitaki pouwhakaata. Ahakoa kei roto $\mathrm{i}$ te reo Paakehaa ngaa whakaaturanga, i a maaua e maatakitaki ana e koorero Maaori ana maaua, he mea whakakata, he mea whakatoi...

The interest in whaikoorero meant that I needed to learn the reo at a certain level, at a formal point, but actually I learnt a lot of te reo by watching television with Pera Tahi. giving and taking, joking...

Kaaore he mea nui te reo moo taaku mahi hai tangata moohio moo te tikanga. I koorero Paakehaa au moo teenaa.

This mix, anthroplogy with the language additive if you like, was accidental in the sense that I did not need it in my paid work as a 'culture guy' talking about Maori culture amongst other cultures in English.

He mea rerekee i te kaupapa o Anthropology inahoki ko te whakaaro nui ko te mahi whakamau i nga tikanga o eetahi taangata kaaore ki te whakarerekee i teenaa, kaaore hoki kee te uru ki te ao koorero o te hapori. I muri ki a Oxford he mea hou teenei ki eetahi. I ai ki a Godfrey Lienhardt, he UFO au.

It was also an anomaly or unusual thing in Anthropologypeople went into the field and wrote about the culture. They did not become participants engaging in the round of public talk. Later at Oxford this was not understood or at least not placed in the scheme of things. Godfrey Lienhardt, he of Divinity and Experience, The Religion of the Dinka fame, called me an 'Unidentified Flying Object'.

Heoi anoo, i teenaa waa, he mea rerekee ki a eetahi peenaa i taaku mahi moo te Pukapuka Kupu Aahua o te Reo Maaori i a Oxford. Ka whakaoti au i te mahi moo teeanaa ki a Oxford tonu. Kei waho o te kaupapa teenei ki a eetahi...

Even then there were curious, curious to others and to an extent to myself, developments. For example as mentioned above Kateraina Mataira had asked me in 1976 to contribute to the Oxford University Press Picture Dictionary of Maori and this I did, finishing things off for the actual publishing of the book in fact in Oxford in 1977 mostly because I just happened to be 
there, much, again, to the curiosity of other anthropologists at Oxford...

I eenei tau, me kii 1975-7 ka haere a Hoani Rangihau ki teenaa hui teenaa raanei ki te Urewera, aa, i eetahi waa i toona taha au. I te nuinga o te waa ka haere kee au i e taha o Pera maa. Ko au te tauhou i waaenganui o Tuuhoe ki te tuawhenua.

In the mid seventies John Rangihau was, of course around in the Urewera at meetings and such and occasionally I would be with him but mostly I would be with Pera and others simply doing things with them such as putting a new floor in Te Whai a te motu in Ruatahuna or a roof on the wharenui Te Poho o Tuhoe in Ohaauaki te rangi. I was the only non Tuhoe working on these houses, both being key places for Te Kooti Rikirangi.

I te Whare Wananga o Taamaki Maakau Rau ka paanui au i ngaa koorero moo ngaa poropiti peenaa i a Rua Kenana me eetahi atu i ngaa waa ako i aarahia naa e Max Rimoldi. Aa, he tino waa ako eenaa. Engari kiihai au i whai i te peenaa ki te Urewera. Naa Pera, naa ngaa tamakiki ki a Tipene Kua tooku whakatutakihanga ki te Urewera, aa, he rerekee anoo ooku whakaaro ki ngaa mea e whai ana i ngaa koorero naa Rua me Te Kooti. Ko te reo teetahi mea, aa, naa teetahi puutake kaaore kau i tino moohiotia e au, ka whai au i teenaa. He koa hoki au moo ngaa aahua o te Urewera wheenaa i te ngaahere tonu.

At Auckland University for my Masters I had studied charismatic leaders under Max Rimoldi. In the Urewera I was not, however, attracted to Rua or Te Kooti whose tracks I was walking. I had come in to the Urewera through Aperahama and others including the boys at Sta Stephens so I had a different attitude, I suppose to others scholars who were usually drawn to the prophets. And for some reason I was taken with the reo. I just liked having fun in the Urewera, building whare, walking the tracks and speaking Maori.

Ko ngaa rangatira, tae hoki raa ki ngaa taane kaha nui kaaore au i pai ai ki a raatou. Ki a au he pai kee taa Wiremu Rowling, aa, kaaore au i pai ki a Muldoon, te taane kaha nui. 
Naa reira i te timata o 1975 ka hono au ki te toorangapuu Reipa, aa, ka tuutaki pai au hai tiamana o te pekanga ki a Maeroa.

Leaders generally, especially those of the strong man type at least did not attract me.This attitude to leadership meant that I actually liked Bill Rowling's leadership of the Labour Party and did not relate to Muldoon, the personalised strong man. And that is why at the beinning of 1975 I joined the Labour Party and became branch chairman at Maeroa where we were living in Hamilton.

He wheenaa teenei ki tooku pai ki ngaa hapori iti, mai pea i a Anthropology teenei whakaaro, he whakaaro pai ki ngaa roopu mahi iti ki te Urewera e koorero ana i too raatou anoo reo moo oo raatou anoo wawata... aa muri ka puea ake teenei whakaaro moo ngaa roopu kaimahi iti, moo ngaa whaanau ki te hapuu me te iwi. Kaaore au i te pai ki ngaa koporeihana nui, aa hoki, kaaore au i pai ai ki ngaa taangata e tuu motuhake rawa ana.

This impacted on and at the same time derived from the small community approach that I had in anthropology, small work groups in the Urewera speaking Maori and sharing common goals...later this interest would show itself in work trusts, labour only gangs and working with a few families in hapu and iwi development. I did not respond to corporates. They were too big and, on the other hand rugged individualism was not for me.

Ko Hoani Rangihau, he tangata Nahinara teenaa, he hoa noo Duncan McIntyre. Ka mea mai toona hoa wahine, a Wena, i paataingia a John hai tangata tuu moo Social Credit i teetahi waa. Ka tohetohe maaua moo eenei momo mea.

John Rangihau. on the other hand, was a National man with Duncan McIntyre a close acquaintance and once, his partner Wena told me, he was asked to stand for Socail Credit. So we would argue about this kind of thing.

He waa anoo kee raa, 1975-6. A muri raa i ngaa tau e tata ana ki a 1990 ka taahuritia anootia eenei mea katoa i te taenga o te kawanatanga Lange-Douglas. I teenaa waa ko au te 
tiamana o te Kaunihera Reipa o Waikato, aa, ki a au he mea pai te nuku i a Kirk ki a Rowling engari he rewanga rerekee teenaa ki te matau me Roger Douglas. Ka rewa noa kee au...

1975-6 was a moment in time though. Later on, jumping into the eighties, with the Lange Douglas government the whole thing changed. I was by then the Chairman of the Waikato Regional Council and found the transition from Kirk to Rowling well and and fine but certainly not the later drift to the Right with Douglas. It left me adrift really...

Ka tuu au moo Waikato i 1985, aa, he waa rerekee mooku. ka toro atu au moo te tautoko mai i te taha maaui engari he maahere rerekee i kitea ai e au. Ka maatakitaki mai a John i eenaa momo mea... he mea rewa hoki ia ki te Centre for Maori Studies.

I stood in Waikato in 1985 and it was an unsettling experience. I would reach out for Left support and find a Labour strategy of, say, deregulation, to hand. John watched all this... he was adrift as well, moving away from others in the Centre for Maori Studies.

Ka haere ia maa runga o toona anoo naa huarahi. Ko Puuaoteatatuu te mea i whai moona, he mea nui teenaa. Ka haere au i te Whare Wananga o Waikato ki a Wikitoria, aa, ka arahi au i eetahi roopu kaimahi ki te tau 1987.

He went his way and I went mine. He proceeded to Puaoteatatu and really made a big mark. I went from Waikato to Victoria University and in a part time capacity there ran labour only gangs until the crash of 1987 .

Kia hoki au ki te waa o 1976 ka tono au ki te haere ki a Oxford, aa, ka haere au ki reira i te tau 1977.

Coming back to the mid seventies, in 1976 I applied to Oxford to do a doctorate and got in, going there in 1977.

Ko Oxford, he ao anoo teenaa inahoki i reira teenaa, teenaa, mai i teenei ao pukapuka. Ahakoa i teeraa taha o te ao i a Aotearoa i a au i reira kei reira hoki ko Hugh Kawharu me tona whanau, ko Bob Mahuta me toona whaanau me Dan Davin, Bob Burchfield me eetahi atu. I reira a Keith Sinclair moo 
teetahi wa poto engari kiihai au i kite i a ia.. Aa, i reira hoki moo eetahi marama ko John Rangihau.

Oxford was interesting as it was a who's who of this particluar academic world. There people were on the other side of the world. While I was there so was Hugh Kawharu and family, so was Bob Mahuta, so was Dan Davin and Bob Burchfield and the OUP set. Keith Sinclair came through at one point although I never saw him. And so, for a time, was John Rangihau.

Ki a Oxford ka haramai teenaa tangata teenaa ki tooku nohoanga moe ai. E whakaaro ana au moo Wayne me Gill Smith me Bronwyn Muir me eetahi hoki i haramai ai kia hoatu waawata, tuumanako hoki ki a au i taku mahi ki reira.

At Oxford people would breeze in and stay. Wayne and Gill Smith, Bronwyn Muir and others came and, to me, gave. They gave hope and fortified my ambition at Oxford.

Ka hari au i a raatou ki ngaa waa ako, ki te kai ki te Kaareti o Wolfson, aa, moo eetahi hiikoitanga i te taha i te awa Isis, ki te hootera raanei. Ka kata tahi, kai tahi, moe tahi hoki ai maatou. Ko John Rangihau, i toona anoo naa haramai ki a Oxford i te tau 1978, aa, i toona anoo naa nukuhanga ki tooku whare noho ai i 1978 ka pai ai ia ki eenaa momo mea. Ka koa ngaa Paakehaa i a ia, he waa tuatahi ma eetahi o raatau e aata koorero ki teetahi Maaori, aa, ko Hoani te tangata!

I would take them to seminars, to lunch in College and for walks beside the river Isis or to the pub. We would dream on together, laugh and talk through the night. When John Rangihau showed up at Oxford in late 1978 and at one point in 1979 moved in with me he liked this sort of thing and he gave a lot to all involved as well with a perspective from another generation, from another culture- some of the Pakeha people staying had had little contact with Maori. People were crossing roads.

Aa, ka pai ngaa taangata ki te kai tahi.

And of course people liked to share kai. 
He mea rerekee te mahi kai ki Ngai Ingarangi. He aahua ohorere raatou moo te maia o ooku manuhiri ki te moe, ki te kai hoki. Moo eetahi raa. Ka mea mai raatou kaaore raatou i moohio $\mathrm{i}$ te rahi o ngaa taangata ki Aotearoa!

The food thing was interesting as the English flatmates were just not used to a constant stream of visitors calling in to eat as well as to say hello. And then to stay for a day or two. They would say things like they didn't realise there were this many people in New Zealand (!).

I koorero au ki te Institute for Social Anthropology moo 'Gun and Dick' me te ao reo ki a Tipene Kura. I muri ka taangia teenei e Pita Ramsay i taana kohinga, The Family and the New Zealand School.

I gave a paper to the Institute for Social Anthropology on Gun and Dick and the language world of St Stephens, a paper that was later published by Peter Ramsay and the educationalists at Waikato University in The Family and The New Zealand School series.

He kino kee te takirua ki Ingarangi $i$ te hurihanga o te tau 78-9. Ka noho a John Rangihau i a au ki Oxford, aa, he iti kee raa te waahi noho. He maataotao hoki raa teenaa waa.

The winter of 78-9 in the UK was especially harsh. John Rangihau was staying with me in Oxford and he and I were living in quite cramped conditions. It was bitterly cold.

Ka whakanaumai te whenua o ngaa Iharaira i toona raa. I teetahi tau i te karapu hui o te Kareti Wolfson ka peti mai tooku hoa noo Aahitereria a Rawiri Waaka kia kore e taea te taraiwa i tooku waka, he 1966 Maaka Toru Zephyr Ono, ki te Whenua Tapu, aa, ko teenaa teenaa, mai i reira ka haere te haere.

The Middle East with its sun beckoned. One night in the Wolfson College Common Room Bar my Aussie mate Dave Walker bet me I could not drive my 1966 Mark Three Zephyr Six to the Holy Land and that was that, it was all on.

Tae hoki i a Hiruharama me te Whenua Tapu ka pirangi hoki au ki te haere ki teetahi waahi e kiia nei ko Opuzen ki te 
wharuarua o Neretva ki Yugoslavia noo te mea noo reira tooku koroua.

As well as Jerusalem and the Holy Land I also wanted to go to a place called Opuzen in the Neretva region in the then Yugoslavia as that was where my grandfather had come from.

'Ka pai,' ka mea mai a Alon, tooku hoa pai mai i te whenua o ngaa Iharaira,' Me haere tono taatou i a Macedonia, aa, e eke taatou ki teetahi waka ki a Greece. Nohou naa,' ka mea mai ia,'te Zephyr Ono me te pae kume, maaku e paatai ki tookuu maatua keekee moo tana tauaru. E kore taatou e noho i ngaa hotera nunui ne.'

'Good enough,' said Alon Kadish, my good Israeli mate, 'we'll go on through Macedonia and then pick up a ferry in Greece. You,' he said, talking to me, 'have the Zephyr Six with a tow bar and I can borrow my uncle's caravan. So we don't need to stay in fancy hotels or anything.'

Kia hoki whakamuri ai moo teetahi waa poto moo teetahi tirohanga whaanui, he rahi maatou, ngaa mea o Niu Tiireni ki Oxford i teenaa waa. Ki reira a Hugh Kawharu, aa, ko te aahua o teenaa hononga moo maaua ko Hugh, ka koorero ia, ka whakarongo ahau. E haerere maua, aa, kia pirangitia au e raaua ko tona hoa whahine a Freda kia tiakina aa raaua tamariki, a Merata me Amokura, ka tahae au i aa ratou kai, paanui pukapuka hoki ki too raatou kainga. He rahi kee ngaa waa koorero i waaenganui i a maatou ko Hugh ko Freda i aa raaua tamariki e noho whakarongo ana, oma rauna, whakatoitoi hoki i etahi wa (!).

To step back for a second and give context, there were several of us from New Zealand at Oxford and we did things together. Hugh Kawharu was there and our relationship was that Hugh talked and I listened. We went places together and if Hugh and his wife Freda needed me to do things like baby sit his daughters, Amokura and Merita then I'd raid the fridge and read a book around at their place. Freda and Hugh and I talked about things a lot with their kids in attendance. 
Ko maaua ko Te Kotahitanga Mahuta, he hoa riiki maaua. He rahi kee ngaa whakatetae i taakarongia ai e maaua moo te kapa riiki o Oxford. Ko Howard Henry mai i a Rarotonga teetahi anoo i too maatou roopu, aa, ka taakaro hoki a Howard i te riiki. Kua hokona te waka, te Zephyr naa e au i a Howard i mua noa i toona hokihanga atu ki te waa kaainga ki Rarotonga, ki reira mahi ai hei takawaaenga kawanatanga. Ko Rawiri Waaka noo Aahitereiria teetahi anoo o ooku hoa i taakaro riiki ki too maatou taha, aa, i purei rakuraku maatou i a maaua e tuu patipati ana ki Raanana, aa, he tangata mohio hoki a Rawiri i a John Rangihau i a ia e noho ana ki tooku whare.

Bob Mahuta and I were Rugby League mates. We played a fair bit of league together for the Oxford University Rugby League team. Howard Henry from the Cook Islands was another person in our set and Howard played league as well. I'd bought the Mark Three Zephyr off Howard a day or so before he had departed for the Cook Islands where he was a Foreign Affairs person. Dave Walker the Australian was a mate of mine who played league with us, busked in London with me on our guitars and got to know John when John was staying with me.

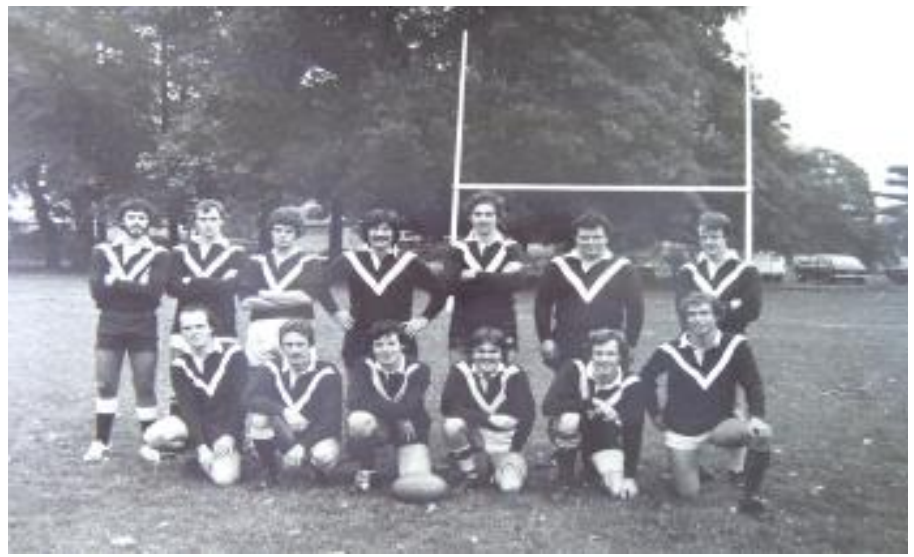

Te Kapa Riiki o Oxford. Kei waaenganui o ngaa mea e tuu ana au. Kei tooku taha maaui a Dave Walker. Ko au te Tumuaki.

The Oxford University Rugny League Team. Dave Walker is on my left. I am the Captain. Photo from Dave Walker's collection. 
He rerekee anoo o maatou wao ki Aotearoa. Hei tauira i waaenganui au i ngaa mea porotete ki Bastion Point engari kaaore a Hugh, he uri noo Ngaati Whaatua ki reira, aa, ko eenei teetahi mea maa maaua e aata whakaaro i a maaua e noho ana ki Oxford.

We all had lives back in New Zealand and sometimes these were very different. For example I had been amongst the protesters at Bastion Point while Hugh had not and Hugh being of Ngati Whatua this was something that we had to come to terms with in Oxford.

He ao rerekee hoki oo maatou ki Oxford. Ko John Rangihau raaua ko Howard Henry, i noho ai raaua ki Te Whare o Kuini Irihaapeti, he waahi moo takawaaenga kaawanatanga mai, me kii, te ao tuatoru me te ao tuawhaa. Ko Te Kootahitanga Maahuta me au, i te Kareti o Wolfson maaua. Ko Hugh Kawharu, ki Hato Antony Kareti ia, a, ka aarahia ai au i teenaa kareti hoki.

And we all had our Oxfords. John Rangihau and Howard Henry were based in Queen Elizabeth House, a site for diplomats and Foreign Affairs people especially those from the Third and Fourth Worlds. Bob and I were at Wolfson College. Hugh Hawharu was at St Antony's College and I was supervised from that college as well.

I te taha, he roopu kiwi i noho ai ki taawahi, aa, ko Dan Davin te tangata $\mathrm{i}$ roo tonu o teenei porohita. He mea koohumuhumu eenei moo teenaa, teenaa mai i Aotearoa, kei hea teenaa, kei te aha teenaa. He mea tata a Bob raaua ko Hugh ki a Dan me toona hoa wahine a Winnie. I eetahi waa ka haere maaua ko John Rangihau ki te koorero ki a Dan Davin maa ki te Gardeners Arms.

In the background were the group of Kiwi expats centred around Dan Davin at the Gardeners Arms. His group kept up a kind of running commentary on who, from New Zealand, was where and doing what. Bob and Hugh were close to Dan and his 
wife Winnie. I would sometimes take John Rangihau to talk to Dan Davin at the Gardeners Arms.

Ko ahau noa nei, he tata rawa pea au ki teetahi mai i a Aotearoa, araa, Ko Bob Burchfield. Ko Bob, peenaa ia i a Dan Davin kei Oxford University Press ia. Ka piri a Bob ki te taha pukapuka kupu.

Personally I was closer to another New Zealander, Bob Burchfield. Bob, like Dan Davin was at the Oxford University Press. Bob being more to do with dictionaries.

Naa eenei moumou mea he ia rerekee o matou ki Oxford engari raa i eetahi waa ka hono eetahi o eenei.

So we all had our different Oxford connections and these ran into one another at times.

Kia hoki ai au ki a John Rangihau na te aha i pirangi ia ki te haere ki Hiruharama? 


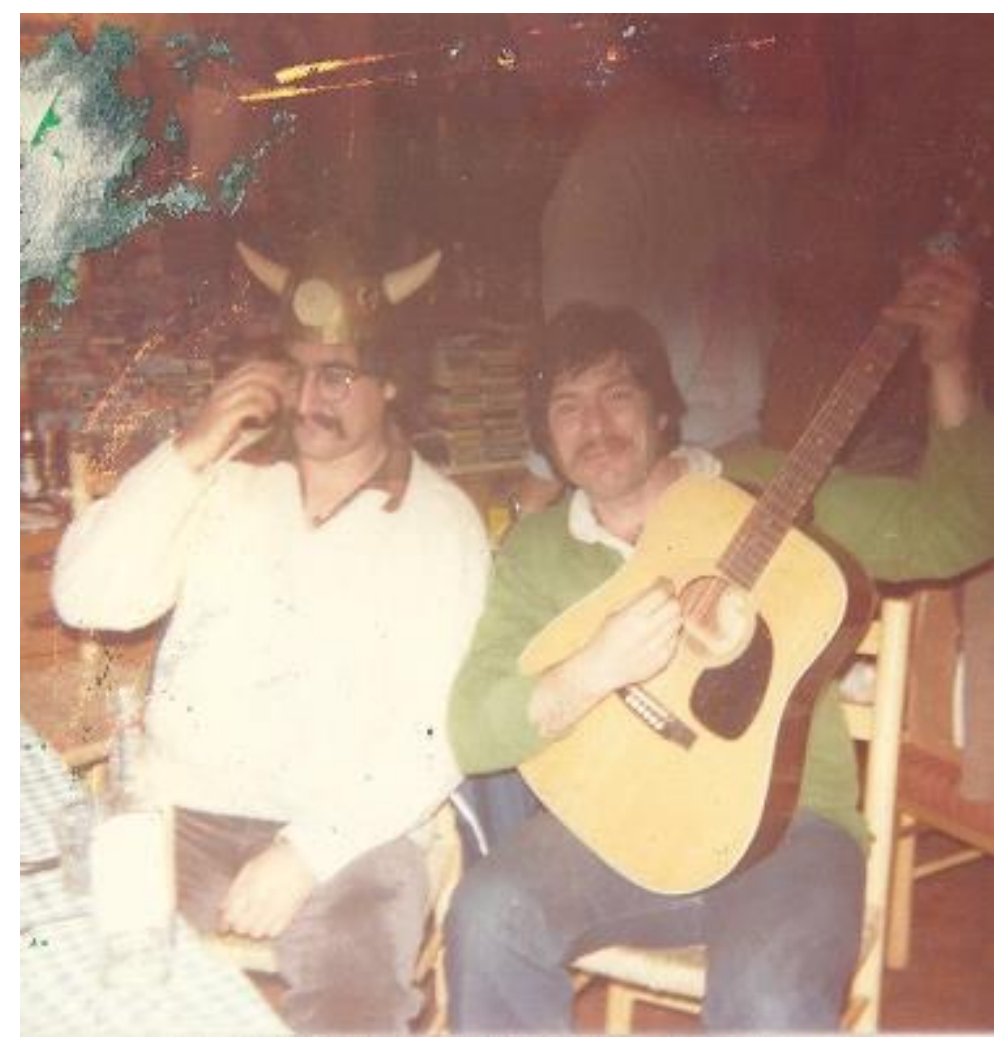

Alon Kadish-in the hat-and myself on guitar

David Walker collection

Coming back to John Rangihau, why did he want to go to Jerusalem?

I te whakaaro moo toona paakeke ka aata wananga au i teenei paatai i a John, aa, e kitea he tino kaha ia ki te haere. Kaaore i te mea kia waihongia ia ki Oxford. Ka waatea tooku ruma moona, aa, he koa kee ia ki reira.

Given his age, sixty or so at the time, I went over this at some length with John and found that he really wanted to come. It was not just a matter of being left on his own in Oxford. He would have had my room to stay in and he was quite comfortable there. 


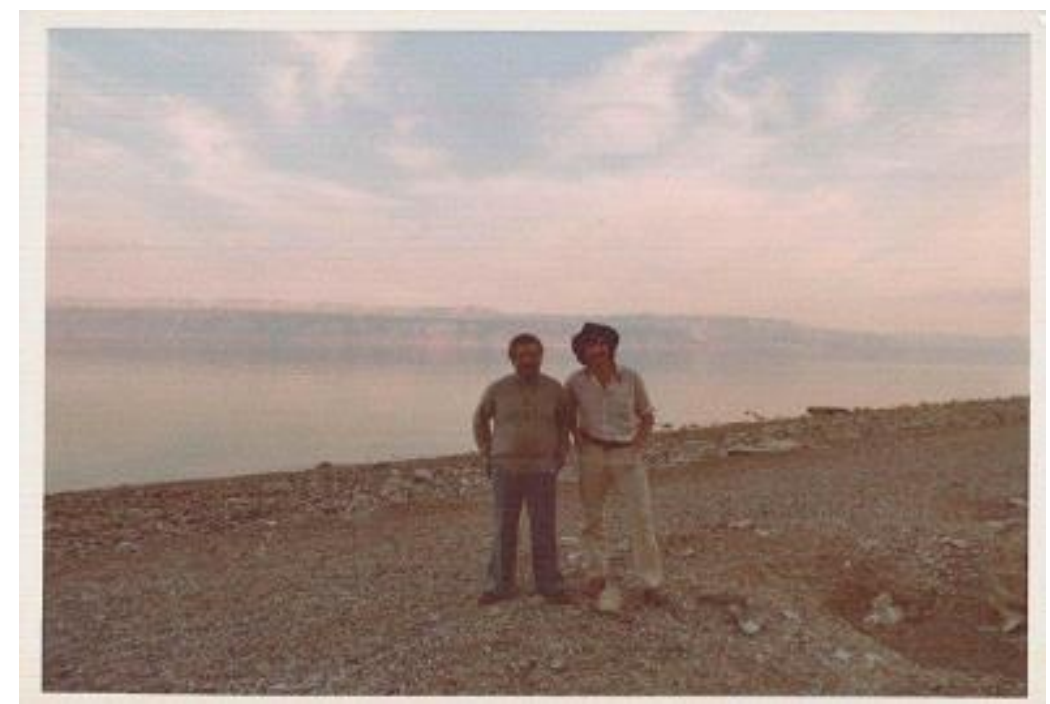

John Rangihau and myself at the Dead Sea Maaua ko Hoani Rangihau ki te Moana Mate Personal Collection- photo by Carol Anne

Aapiti ki te puutake o te makariri me te whakaaaro kia wehea teenaa ko te mahere kia haere ai maatou maa Opucino me nga waahi peenaa e moohiotia e John i te Pakanga Tuarua. Ki tua o teenaa ngaa mea katoa moo te Whenua Tapu, Ngaa Iharaira, te rangatiratanga o ngaa Huurae me Te Kooti, Rua Kenana, te Haahi Ringatuu, te iwi o Tuuhoe hoki. 


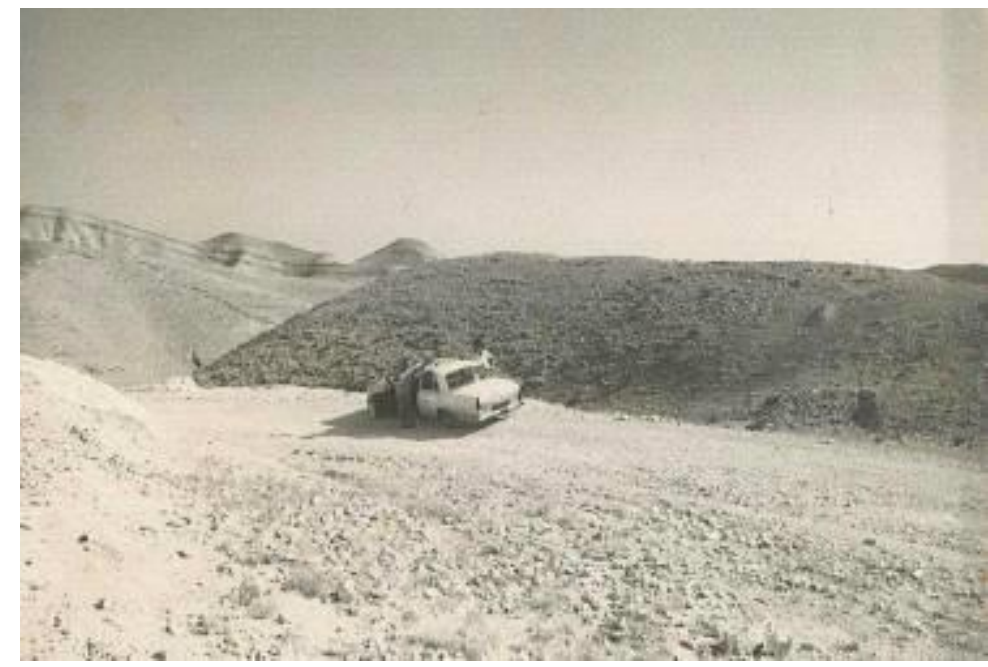

Maaua ko John Rangihau me te Zephyr i waaenganui i a

Hiruhaarama me te Moana Mate

John Rangihau and myself with the Mark Three Zephyr between

Jerusalem and the Dead Sea

Personal collection- photo by Carol Anne

As well as it being cold and needing to get away from that we were going via Opucino and places that John had fought in during the Second World War. Then there was the whole business of the Holy Land, Nga Iharaira, the Israelites and Jewish self determination and Te Kooti and Rua Kenana, the Ringatu Church and the Tuhoe iwi.

Teeraa pea maa teenaa teenaa e whai i nga aronga peenei kia whakaarongia ngaa mea o te Urewera. Ko tooku mohio he paku matauranga pea moo ngaa waahi ki roo tonu i te ngaahere peenaa i a Taawhiwhi, Ngahiramai me Ohaaua, aa, ki tua o eenei waahi ki te ngaahere i Te Panaa me kii. Engari i ngaa waahi taangata peenaa i a Uwhiarae Paa i eetahi waahi ki Ruatahuna, Ruatoki, Waimana raanei he tuuturu kee Ngaa Iharaira.

To some extent these things were localised in the Urewera. My own experience had been deep in the bush at Tawhiwhi, 
Ngahiramai, Ohaua and deeper into the bush at Te Panaa. But in the social places like Uwhiarae $\mathrm{Pa}$ and elsewhere in Ruatahuna or in Ruatoki or Waimana back then the Iharaira were very real.

Ki ahau noa, ko Uwhiarae, ko Maungapoohatu, he waahi eenei i moohiotia ai e au engari kaaore au i te tino moohio rawa atu i eenei wahi. I kitea ai e te tangata ngaa mea matatau moo eenei mea i ngaa hui peeraa i ngaa Tekau Ma Rua. Ki Maungapohatu i kitea ai e te tangata ngaa mea peenaa i a Smoky me John Tahuri, nga mea i tiaki ai i te paa taawhito o Rua. I teeraa waa ko tooku whakaaro e tika ana kia waiho te paa i runga i toona anoo mana.

To me Uwhiarae and Maungapohatu were places that I knew but they were places that I did not really understand. You would see people at hui such as Twelfths who were right into this sort of thing. At Maungapohatu you might see Smoky or John Tahuri, the people looking after the place but what was left of Rua's village was something that you respected and left alone.

Engari ka moohio a John i eenei waahi me eenei taangata, aa, he mea nui ngaa waahi peenaa i a Hiruhaarama, Ngaa Huurae, Ngaa Iharaira ki a ia, aa, he orite oo John ki nga whakaaro o eetahi mai i te Haahi Ringatuu.

But John did know these places and people and was of them and Jerusalem, Hiruhaarama, Ngaa Huurae, Nga Iharaira and all that meant a lot to him as they did to other Ringatu people. 


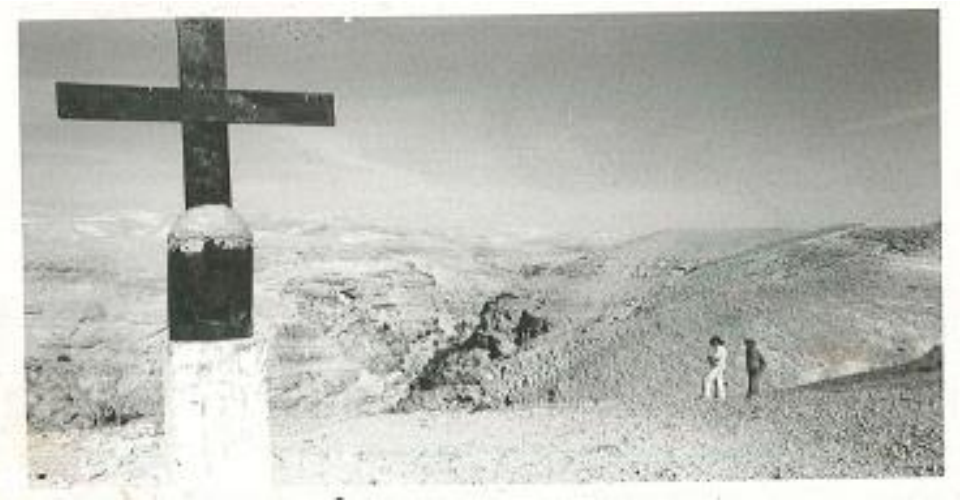

\section{Maaua ko John Rangihau i waaenganui i a Hiruhaarama me re Moana Mate \\ John Rangihau and myself between Jerusalem and the Dead Sea Personal collection- photo by Carol Anne}

I te whiringa kia haere ai a John ka tuutuki au i a Hugh Kawharu me eetahi mai i te Whare Niu Tireni ki Raanana. Kaore raatou i pai a ki toona haere inahoki he haerenga roa, he wahi uaua nga wahi pakanga i te haere, he awangawanga hoki moo te hauora o John, aa, he paatai hoki moo te aahua o te haere maa runga $i$ te Zephyr Six e kume ana i teetahi tauaru? He taaonga o Aotearoa a John, aa, he aahua matuku a Hugh maa moo too John haere.

In making the decision to have him along if he wanted to come I went up against Hugh Kawharu and one or two people from New Zealand House. They were against him making the journey as it was a long way, it was a bit rough over there, war zones and all, and there were concerns for John's health and the way were going- in a caravan behind an old Mark Three Zephyr Six? John was a national taonga in New Zealand and this was all a bit risky to Hugh and them.

Heoi anoo, ka mahi au i te waka. I mua raa kua whakahoungia e au te puu i te taha o te huarahi ki waho o te whare o tooku hoa, a Eric Tracey ki Ranana, aa, ka whakatikatika au i nga taea me ngaa mea katoa moo te waka. 
In any event I got down to it with the Zephyr. At an earlier stage I'd put a new motor in it on the side of the road outside my mate Eric Tracey's place in London and I now checked the tyres and the rest of the car.

I te raa wehe ka whakataetae maatou i ngaa mea o Peckham ki Raanana. Ka panaia au ki te taha e te Kaiwhakawa na teetahi mahi mekemeke. Ko Peckham he karapu mai i nga toenga o Millwall ngaa mea i aukatihia i nga waahi hutupooro, noo reira ko teenei teetahi mea. Kaaore a Hugh Kawharu- kua haramai a Hugh i te mea e haere ana ki te tauranga waka rererangi ki Raanana- i pai ai ki teenaa.

On the day of departure we played Rugby League at Peckham. I got sent off for rough play and against Peckham, a club made up of people banned from Millwall soccer club because of football hooliganism, that was something. Hugh Kawharu who came to watch the game en route to catch a plane home was not impressed.

I muri i te waa taakaro ka hono maatou ko John ko Alon Kadish i tetauaru, aa, ka eke maatou ki te waka, aa, ka haere maatou. I mua i too maatou wehenga ka hoko maatou i ngaa kai me eetahi atu mea moo te haere.

And after the game John, Alon Kadish and I hitched up the caravan, climbed into the Mark Three and off we went. Before we got onto the ferry at Cardiff we stocked up with supplies.

Ko au te taraiwa i te katoa o te haere inahoki kaore a Alon $\mathrm{i}$ taraiwa, aa, Kaaore a John i te pai kia taraiwa ai ia. 
I was the driver throughout as Alon did not drive and John did not think it was a good idea for him to drive.

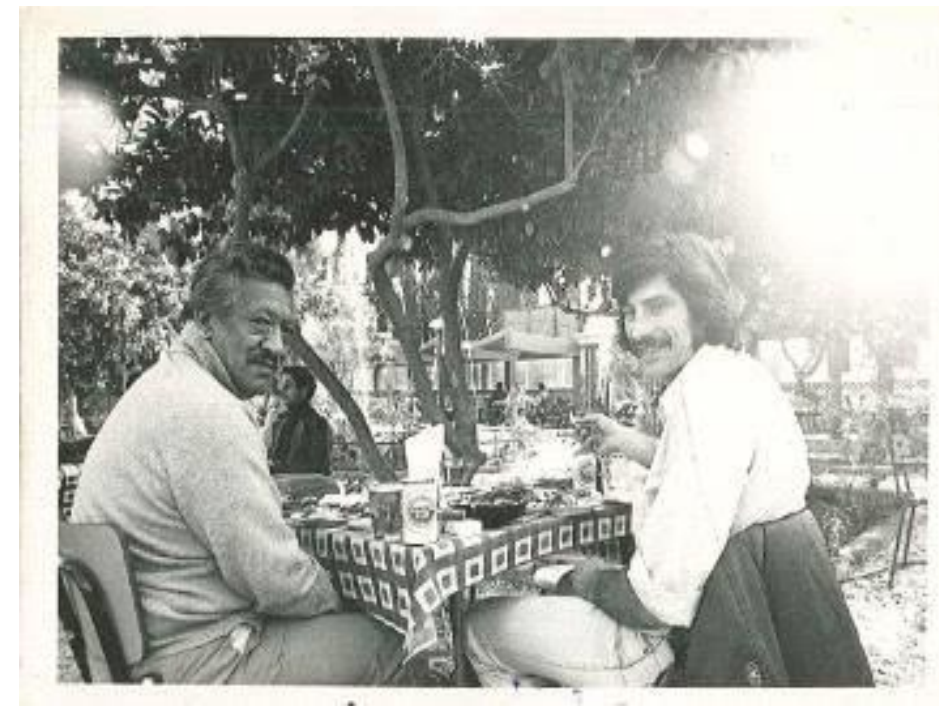

\section{Maaua ko Hoani Rangihau i teetahi wharekai ki a Jericho John Rangihau and myself in a cafe in Jericho Personal collection- photo by Carol Anne}

Ka pai te haere maa runga waka tere ki Calais. Ka tuu maatou $i$ te taha o te rahoraho $i$ a maatou e maatakitaki ana $i$ te moana. Ka haere a Hone ki roto moo eetahi paku moe i teetahi waa.

The Ferry from Calais was uneventful and we stood quietly at the rail of the boat looking at the sea. John had a bit of a snooze inside at one stage.

Ko te mea tuatahi i paa ai ki ahau i te wehe i te waka

E taraiwa ana au i te taha kino o te huarahi me te tauaru ki muri, aa, he roa kee te waa maaku e pai ai ki teenaa.

The first thing to hit me on driving off the ferry was that I was driving on the wrong side of the road with a caravan behind and that took a bit of getting used to.

Ko maaua ko Hoani, ka kata maaua i a maaua anoo mena e kitea teetahi mea rerekee, aa, ka peenei te koorero 
'E Taa, he rawe kia kitea ai teenaa e Hugh Kawharu!', teeraa pea, 'He ohorere kee a Hugh moo teenaa!'

John and I would make cracks as we went if something seemed extraordinary or strange and say things like, 'Wow, I wish Hugh Kawharu could see this!' or 'I bet Hugh'd have a fit!'

Teeraa pea raanei, He mea pai rawa kua haramai a Raawiri Waaka.E hoa e!'

Or, 'Dave Walker should have come!Mate!'

Teeraa pea 'Ko tooku wawata kia kitea ai e Howard to matou haere i tona waka!'

Or,'I wish Howard Henry could see where we've gone in his car.'

Teeraa pea, 'E kore e kore kua pai a Bob Mahuta i teenei!'.

Or, 'Bob Mahuta would be right into this!'

Ka taraiwa maatou i ngaa huarahi o Wiiwii, i teenaa kaainga ki teenaa tae rawa atu ki a Paris. Kua pouriuri i too maatou tatanga atu ki reira. Tae atu rawa maatou ki reira ka taraiwa au i teetahi porohita nui i ngaa taha o te taaone. Paahemo rawa atutia te taaone ka tuu maatou. Ka kai maatou i too taatou caravan, aa, ka moe maatou. Tokorua o maatou ka moe i ngaa pae kei te taha o te caravan, kootahi ka moe ki te kaupapa. Ko teenei too maatou kaainga moo ngaa raa i whai ake.

We drove across France, village after village, and on to Paris. Night was falling as we approached. When we got there I just kept driving around what seemed to be a huge ring road. Finally we were past the city and we pulled over. Had a meal in our caravan and went to sleep, two on benches and one on the floor of the caravan. This was to be our home for the next few days.

I a maatou e takoto ana i te caravan ka koorero noa maatou, aa, ka katakata maatou i a maatou. Teeraa pea ki reira kee koe. Teeraa pea ka mea atu au 'He pai kee meenaa kei koonei a Hugh kia pai ai ia ki ngaapiini makariri!' Ka kata rawa a John i teenei. Ko teenei pea he torohanga atu i nga raa ki tooku ruma i Oxford. I eetahi waa kua haramai a PCB Phillips mai i te Tari Putea ki Birmingham, aa, ka takoto te tokotoru o maatou i te kaupapa kiikii rawa atu i tooku ruma i a maatou e kata nui ana. Mai i 
tetahi tirohanga he mea whakahou teenei ki a John. He mea matatau ia mo te noho aa whaanau engari i teenaa waa ko te ahua, he koa kee ia moo ngaa mea i koorerongia e maatou. Ko teenei teetahi wahanga taumaha o toona oranga engari raa ki a maatou kaaore $\mathrm{i}$ te pai kia taumaha rawa atu teenaa mea, teenaa raanei.

Lying in the caravan we would all yarn away and tell silly jokes. You had to be there. I might say, 'Wish Hugh was here for the cold beans we had for tea' and John would crack up! This in itself was an extension from happenings in my room in Oxford. Sometimes my mate P C B Philips who was running Economics at Birmingham would come down to Oxford and stay and the three of us would be crammed into my room all talking away and laughing till all hours of the night. In a way this was refreshing to John. He was used to communal living and all that but he really seemed to like the things we talked about and the things we got up to. He was at a time in life when things were to be taken really seriously whereas for us, me and my friends, it was more a matter of taking the mickey and never taking anything too seriously.

Heoi ano ka wehe maatou ki te tonga o Wiiwii me te raa.

And so we set out for the south of France and the sun.

Kaaore kau he paru i ngaa huarahi, ngaa tuuranga, ngaa wharekai me ngaa waahi katoa kia whakaarongia ngaa mea peenaa ki a Ingarangi. He tino ohorere au i te pai o tooku reo Wiiwii noo te mea he paapaku kee tooku moohio i teenaa reo mai i te Haikura o Manurewa- he itiiti kee ooku waa ako-i te mea ka taea te nuinga o ngaa waa e maatou, aa, ko au te kaikoorero..

The French motorways were so clean, the stops, the cafes etc compared to England. To my amazement I found that High School French from Manurewa High- where I had only very occasionally attended class in my last year there- got me- and us- by in France.

Engari, ka whati te waka. Kua tunua nga waea hiko i te Zephyr. 
But we broke down. Wires in the Zephyr had fried.

Ka haere a John raaua ko Alon ki teetahi wharekai Wiiwii. John and Alon went to a Cafe.

Naaku te whakahou i ngaa waea hiko i eetahi ngongo rerekee $\mathrm{i}$ te puutu o te waka. Ka haramai eetahi taangata whenua, aa, ka whakahoahoa raatou i a au i a ratau e matakitaki ana i taaku mahi whakahou i nga ngongo hiko, ka kata eetahi, ka miharo eetahi, he waa koa maa te katoa!

I had to rewire the car on the side of the road with chunky electrical wire that I had in the boot. Locals came and made friends as they saw the way the motor was being wired and went on and on about it and we had a great time!

I muri i te hekenga o eenei huarahi roa- he whenua nui a Wiiwii- ka noho maatou i teetahi puni waka ki Cannes.

After coming down these long motorways- France is a big place- we stayed in a motor camp in Cannes.

Ko taa Alon mahi kia panui ia i te mahere,kite ki hea kia wehe ai maatou i te huarahi, aa, kia mahi i te mihini waiata. He rawe kee a John moo ngaa Andrews Sisters peenaa o te Chattanooga Choochoo. I eetahi waa ka mea maatou i a maatou, 'Pardon me boys...'

It was Alon's job to read the map, see where to turn off, see where the places to stay might be, and attend to playing the music on a tape recorder that we had. John was great on old Andrews Sisters recordings like Chattanooga Choo Choo and we would banter amongst ourselves with lines from these songs like 'Pardon me boys...'

Ko taa John mahi kia moe ai ia ki muri, kia oho ai ia korero ai moo te iwi o Tuuhoe, te kawa raanei. Ka taraiwa au, ka taraiwa...Ko John, ka korero roa ia moo ngaa mea nui ki a ia. Kia tata maatou i a Itaria ka koorero ia moo toona waa ki reira $i$ te pakanga tuarua. I eetahi waa ka koorero ia moo 'te Kaanara'. Ko Pita Awatere teenaa. He mea tata rawa a John raaua tahi ko Pita. E ai ki te mahara ka haere te tokorua nei ki te taua rererangi i te mea tuatahi, aa, ka neke raaua ki te Hokowhitu a 
Tuu. I te katoa o oo raaua oranga ka mahi tahi raaua tae hoki raa ki taa John tautoko i a Pita i teetahi waa ki te Kooti.

John's job was to nap in the back and then wake up and deliver long homilies on the Tuhoe Nation or the kawa. I drove and drove. John talked at length about people who mattered to him. As the trip neared Italy he yarned about his experiences there in World War Two. Often he talked about the Colonel. This was Pita Awatere. John Rangihau and the Colonel had been close. From memory they had joined the Air Force at first and then crossed over into the Maori Battalion. Over a lifetime they had done things together and that included John being a witness at a trial involving Pita back in New Zealand.

I teenei waa ko te Awatere o te pakanga i koorerongia ai e John i te tuuru whakamuri o te waka. Ko te rangatiratanga mai i mua me eenaa moumou aahua i te Kaanara e maatau ana ki te purei hutuporo i te kapa o te Hokowhitu a Tuu me te taraka paati i muri i te raarangi waka i te ekenga i a Itaria.

In this case it was the Awatere of the war that John would talk about in the back seat. Leadership from the front and all that as the Colonel insisted on playing rugby in the Maori Battalion team or the blind eye to the party truck at the back of the convoy as they came up through Italy. 


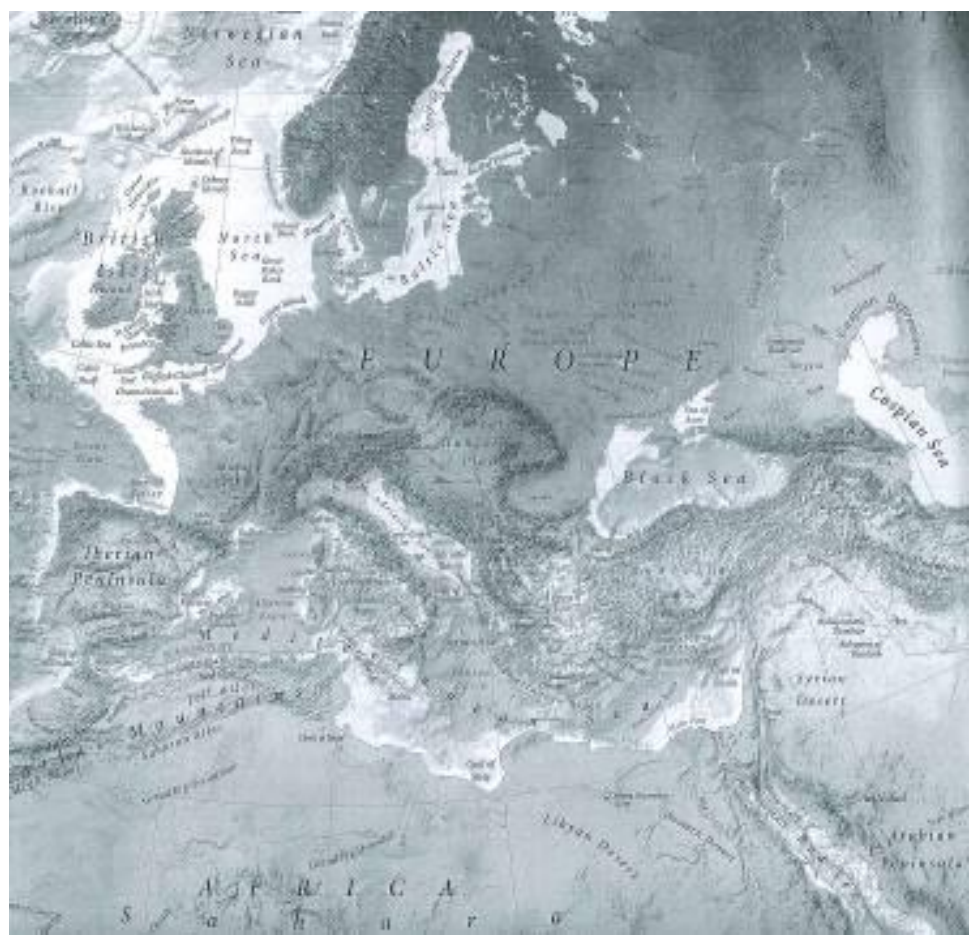

\section{A map of England, Europe and Israel Ingarangi, Uropi me Israel/Palestine Time World Atlas}

Ki Alon, mai i te ropu hooia o ngaa Iharaira, he tino toa ngaa mea o te Hokowhitu a Tuu me eetahi hooia mai i a Aotearoa, he peenaa enei i ngaa sabra. Naa teenaa ka maatau tonu ia ki te paatai i a Hone moo eenei moumou mea, aa, naa teenaa he rahi te koorero moo te Hokowhitu a Tuu, te pakanga ki Itaria, te Colonel hoki. Ka koorero hoki maatou moo te hitori o ngaa Iharaiara me aa raatou anoo pakanga mai i te wa o Massada.

Alon, from the Israeli Army had this idea of the Maori Battalion and other New Zealand fighters as Very Brave Chaps like the Israel Sabra. So he kept questioning John and this meant a pretty thorough review of the Maori Battalion, the Italian Campaign and the Colonel as well as often returning to 
a conversation about the Six Day War and the history of Jewish resistance going back to Massada.

$\mathrm{Ki}$ a au noa, he tamaiti mai i a Manurewa he rangona koorero hou eenei mea katoa, aa, ka nohopuku au, aa, ka taraiwa tonu au.

As a kid from Manurewa it was all, the Tuuhoe angle and the Jewish perspective, news to me and I mostly kept it zipped, listened and drove and drove.

I teenaa waa wheenaa i a waa katoa, he tangata mai i a Waikaremoana a John. Ka tuhi ia ki a Lavinia, toona whanaunga ki reira, aa, ka koorero maatou moo te hitori o Waikaremoana me ngaa mea rongonui mai i reira. Ko au taana taraiwa i eetahi waa i mua i a maaua e haere ana ki reira ki te korero mot e hokihanga o te roto, te moana. Kia tika ai teenei ka haere a John ki te koorero ki teenaa aapiha, teenaa tangata rongonui raanei, te whakahou o te wharenui ki Te Kuuhaa raanei, ko au, ka taraiwa au, aa, ka haere au ki aaku anoo naa mahi ki reira. I eenaa tau kaaore anoo kia haangaia anootia a Waimako.

At this time as always John was very much a Waikaremoana man. He wrote regularly to Lavinia, his cousin there and we talked a lot about the history of Waikaremoana and its famous sons and daughters. I'd been his driver on several occasions earlier in life when we went to Waikaremoana to discuss the return of the lake. That is John discussed this with some official or dignitary or the restoration of Te Kuha meeting house, a painted house, while I did other things. In those years the meeting house at Waimako had not been rebuilt.

I te nuinga o te waa $i$ eenei raa i muri i teetahi taraiwa roa mai i a Hamutana- ka noho maaua ki reira- i roo tonu i te Takirua i te eetahi waa ka moe au i a John e whakahaere ana $i$ aana mea, aa, ka moe ia i a au e taraiwa ana. He mea tuuroa teenei, aa, ka aapitihia a Alon inaianei. Naana anoo pea $\mathrm{i}$ whakaapiti ia i nga waa pai ki a ia.,

Typically on those occasions after a long drive from Hamilton where we were both living, often in the winter, I would 
sleep while John did business while he would then sleep when I drove so this was a long standing set up to which we added Alon, or, should I say, he engaged in as he wanted to.

He aapiha i ngaa hooia o Iharaira, aa, he aakonga tino koa $\mathrm{i}$ te hiitore, he tangata kaha kee a Alon ki te whai i ngaa mea peenaa i te tino rangatiratanga. Noo reira he rahi kee te koorero moo te tuu o teenaa iwi teenaa raanei ki too raatou anoo naa whenua me ngaa mea peenaa. Ko au ka taraiwa tonu.

As an officer in the Israeli Army and a student of history Alon was interested in self determination so there was an almost never- ending korero about the right of a people to exist, tino rangatiratanga and so on. I just drove and listened.

Ka whakaaro hoki maatou moo too maatou ara, ko wai i haere i runga o eenei ara i ngaa waa o mua, aa, he aha te puutake o too maatou whiringa $\mathrm{i}$ teenei. Ka puta mai te whakaaro o ngaa Crusades, ngaa haerenga o ngaa karaitiana ki a Hiruhaarama, ngaa Arabs ki a Mecca me Medina me ngaa mea peeraa.

We were also, I suppose, thinking about the route, who had been down or along it before and why we were taking it. Obviously the Crusades came to mind and we talked about that kind of thing as well as the idea of pilgrimages, Christians to Jerusalem, Muslims to Mecca and Medina and so on.

Ehara i te mea ka mahi tahi maatou i ngaa waa katoa. I eetahi waa ka mahi ngaatahi maatou, i eetahi wa ka haere takitahi teenaa. teenaa raanei, kia hono anoo mai raa hai toona anoo waa. I teetahi waa ki Aotearoa, he aahua mate a Hoani, a, ka haere au maa runga waka ki a Te Waimana, ki reira ka whaikoorero au ki teetahi tangata kapoo naana naa $\mathrm{i}$ whakanaumai i a au ki te marae, ka whakatakoto au i te koha i meatia mai e John, ka kaputii au, aa ka hoki au ki te kaainga ki Hamutana.

We did not always have to be together. It was a matter of being together, separating and then linking up again. On one occasion in New Zealand when John was ill I drove from Hamilton to Waimana on my own, gave a whaikorero to a blind 
man who had welcomed me onto the marae, put down the koha that John wanted given, had a cup of tea and drove back to Hamilton.

Naa reira ko te whakaaro nui kia haere tahi ai maatou engari kaaore kau he mea tata rawa maatou.

So the general idea was that we were in things together but we did not have to be in one another's pockets all the time.

I muri o teenaa ka haere tonu maatou i te French Riviera, aa, ki te Tokerau o Itaria maa runga $\mathrm{i}$ eetahi ara miharo $\mathrm{i}$ hangaia ai e Mussolini.

And then it was on through the French Riviera and into Northern Italy across this incredible road system of high bridges that had, it was said, been constructed by Mussolini.

Ki Itaria ka haere maatou i te tokerau ki tua o Milan, aa, ka taraiwa tonu au kia tuu mauiui ai au- he makariri anoo inahoki kua eke maatou i te Riviera, aa, ka piki maatou, he whaaiti kee nga taha o te caravan- ka noho maatou i tetahi waahi noho waka. I toku ohohanga ka hikoikoi au i tetahi waa tiakina rawatia e eetahi kuri ririri, naa teenaa he tere kee too maatou wehenga.

In Italy we went through the north past Milan and I drove till I dropped- it was cold again as we'd left the Riviera well behind and climbed and the caravan was not well insulated so I wanted to get to the sun- and we stayed in a lay by. When I woke up I walked around and we were near a highly guarded area with big dogs snarling so we were off quick smart.

I te raa i whai ake ka haere maatou ki Trieste, aa, ka maatakitaki maatou i a Opucino me Venice.

Next day we headed for Trieste and had a look at Opucino and then Venice.

I muri o teenaa ka haere maatou ki te ripa o Yugoslavia. I koonei ka whakataahuritia maatou! Ko te take pea, he aapiha a Alon i te roopu hooia o Israel, aa i te pakanga a Yugoslavia me Israel.

Then it was on to the border with Yugoslavia. Here we got turned back! Something to do with Alon being in the Israeli 
Army as an officer and Yugoslavia being officially at war with Israel.

He mea rerekee teenei. Naa teenei kaaore au i te hono i ooku whanaunga ki Dalmatia, aa, kaaore maatou i haere maa runga whenua, maa Macedonia ki a Greece.

This was one for the books. It meant missing Dalmatia and my rellies and not going overland through Macedonia to Greece.

E aha maatou?

What to do next?

I whiri maatou ki te haere maa runga waka i Trieste ki a Haifa ki te whenua o nga Iharaira.

We decided to take a ferry from Trieste to Haifa in Israel.

Ko teetahi mea pai, ka noho maatou i teetahi wharenoho maunga (mountain hostel), aa, he pai teenaa inahoki i waho o te tauaru maatou. Ka inu maatou i te waipiro o teenaa whenua, te Slivovitz. I haere maatou ki te moe i runga moenga i mua $\mathrm{i}$ teetahi ahi tuwhera nui ki runga o te kaupapa kohatu.

One good thing was that we stayed in a mountain hostel that night and we were out of the caravan. We tried slivovitz, the local liquor. Then went to sleep beside a giant fireplace on mattresses put down on a stone floor.

I te raa $i$ whai ake $i$ runga $i$ te waka maatou. He haerenga aa waka tino pai rawa teenei! I haere maatou i te taha o te tai o Yugoslavia. Ka whakaatu au ki ooku whanaunga i a maatou e pahemo ana i te tai o Dalmatia. I muri i te mahi taraiwa, he koa kee au ki te whakangahau. He mea nguengue rawa i a au a Hoani raaua ko Alon. Teeraa pea, he aahua mate raaua engari ka pai haere raaua $\mathrm{i}$ te whakaotinga o te haere.

Next day we were on the ferry. What a great ferry trip! We went down the coast of Yugoslavia. Waved at my relations as we passed the Dalmation coast. After all that driving I was ready to party and make friends and did so. Alon and John were a bit a more subdued. In fact they were off their tucker but they came right towards the end of the voyage.

I muri i nga tai o Dalmatia, Montenegro me Albania, ka haere tonu maatou ki te Corinth Canal, aa, ki te tauranga o 
Piraeus ki Greece. He rawe teenaa, aa, ka kai maatou i eetahi kai reka o Greece. I reira ka haere maatou i ngaa tai ki a Rhoddos, ki te taha o Turkey, aa, ki te Tauranga o Haifa.

After the coasts of Dalmatia, Montenegro and Albania it was into the Corinth Canal and on to the port of Piraeus in Greece. That was fun and we had a great Greek meal. Then on through the seas, past the isle of Rhoddos, along the Turkish coast and then to the port of Haifa.

Inaianei ka puta mai te raa, aa, he tino pai teeraa. Ko teenei te too whakamutunga ki a Hiruhaarama, aa, ka hono maatou i te tauaru, aa, ka wehe maatou.

At last we had sun and it was great. Now it was time for the final haul to Jerusalem and we connected the caravan and set out. 


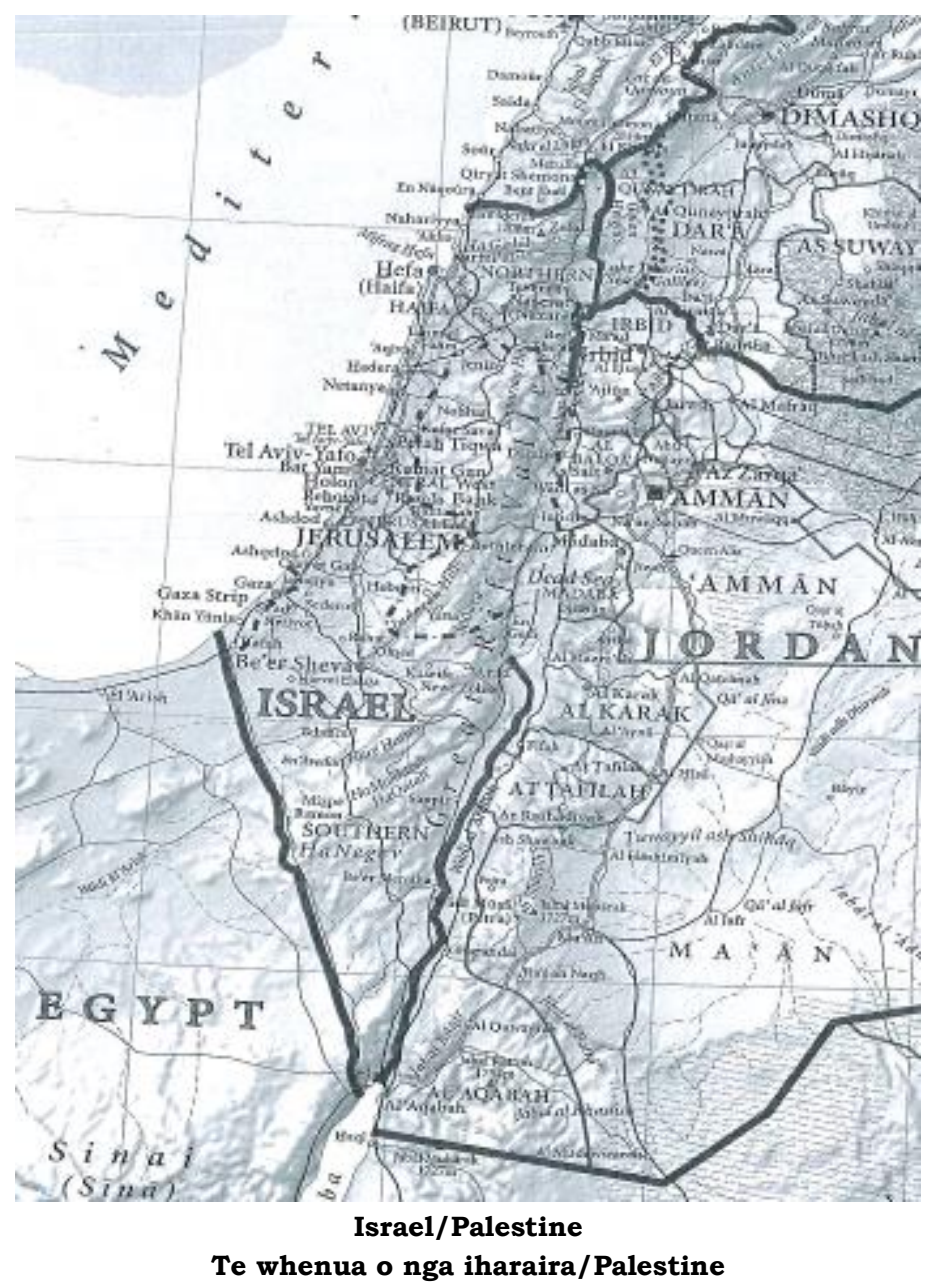

Ko te whare o Alon, he tino tika teenaa. Ka whaia ngaa tikanga katoa i runga anoo i nga mea tuku iho mai raano tae rawa atu ki te kai kosher. Ko te hummus me te hinu ooriwa. Me eetahi manga mata.

Alon's place was the real deal. Everything was done in accordance with customs passed down through the centuries 
and that included the diet which was strictly kosher. Hummus and olive oil. All sorts of salad.

He whare taawhito too Alon, kaaore he teitei ngaa tuani, aa, he rerekee anoo ki ngaa whare o Aotearoa. He waahi pai maa nga mea e pai ana ki te miiti me ngaa ahuwhenua ki te whakawhaaiti i te tinana. Kaaore kau he waipiro.

It was an ancient house with low ceilings and very different to New Zealand houses. A good place for meat and veg types to lose weight. No booze.

Ko Carol Anne, he whanaunga no Alon, ka pai ia i a maatou, aa, ka whakaatu i a maatou ki a Hiruhaarama. Kaaore anoo eenei taangata kia tuutaki i teetahi Maaori i ngaa waa o mua, aa, he pai te whakaaro o teenaa teenaa raanei ki a Hoani me toona anoo naa wairua. Ko au, i te tuatahi ka whakangahau ahau!

And Carol Anne, Alon's cousin took an interest in us and showed us around. They had never met a Maori person before and John was very highly regarded by people and had his natural presence about him anyway. Me, at first I relaxed and had a ball!

Engari kia pau ai eetahi raa ka aata maatakitaki maatou i a Hiruhaarama. Ka hiikoi maatou i nga teihana o te riipeka, te ara o Ihu ki te riipeka. Ka haere atu maatou ki a Jericho, ki te moana mate hoki. Ka haere maatou ki a Bethlehem. Ka haere maatou ki eetahi waahi maumahara moo ngaa mea mate. Ko teetahi mea nui moo maatou ko te hiikoikoi i ngaa ara o Hiruhaarama. Ko Hoani, ka karakia ia i nga karakia Ringatuu e tika ana i a maatou e haerere ana.

But after a day or so we did the Jerusalem thing properly. We walked the Stations of the Cross, the route Jesus took to the cross. We went to the Wailing Wall. We travelled out to Jericho and we went to the Dead Sea. We went to Bethlehem. We went to the Memorial for the Holocaust and most of all we walked around the old city of Jerusalem with its bazaar and narrow alleys. John did the appropriate Ringatu karakia as we went.

He waahi anoo teenaa! Te Whenua Tapu! 
What a place! The Holy Land.

I mua i too maatou moohio kua mutu, aa, e wehe ana maatou ki te waa kaainga.

And before we knew it it was all over and we were on our way home.

Ka rere a John raaua tahi ko Alon ki a Venice. Ka haere au me te waka maa runga waka kia tuutaki maatou ki reira. I reira ka taraiwa maatou ki te makariri o Uropi. Maa runga i a Mt Blanc. Kaore kau he here i te huka taumaha. He mea anoo teeraa!

John and Alon flew to Venice. I took a ferry with the car and met them there. Then we drove back into the cold of Europe. Over Mt Blanc. Without chains in the heavy snow. That was fun.

I too maatou taenga ki a Calais kua pau kee tooku hau, aa, ka haere tootika au ki te moenga i te waka.

When we got to Calais I was exhausted and crashed into a bunk on the ferry.

$\mathrm{Ki}$ Ingarangi anoo, he makariri engari he pai kee te hokihangamai.

Then it was England again, cold but good to be back, just the same.

I muri i eetahi wiki ki a Oxford ka tau mai te waa kia haria a John ki te waka rererangi ki Aotearoa. I mua o teenaa ka whai taima maaua ki te haere ki a Dan Davin me Ngai Kiwi ki te Gardeners Arms. Eetahi tau i muri o teenei ka haere au ki te Gardeners Arms, aa, ka mea anoo a Dan i te koorero moo te haerenga ki Hiruhaarama, aa, kua hono teenaa koorero ki ngaa koorero i meatia, i meatia anootia hoki ai ki reira e Dan, me tona hoa wahine, a Winnie, me nga Kiwi ki reira.

After a few weeks back in Oxford it was time to put John on a plane back to New Zealand. We had time to go and see Dan Davin and the crew of Kiwis at the Gardeners Arms. Years later I showed up there and Dan went over the trip to Jerusalem with me so it had become a story to fit into the snug of yarns that Dan, Winnie and the Kiwis told and retold at the Gardeners Arms. 
Eetahi raa i muri i te hari i a John ki Raanana hoki ki Aotearoa ai, ka whiri au kia hokona ai te Zephyr Tuatoru hei kuha metara. Rima tekau pauna te utu, aa, ka haere maaua tahi ko Dave Walker moo teetahi pia.

A few days after taking John to London en route to New Zealand I shook hands with myself and took the Mark Three to a scrap metal merchant. I got fifty quid for it and took Dave Walker out for a beer.

Ko Rawiri, ka haere tonu ia i aana hakinakina, taana mahi rangahau hoki, aa, i muri o tona hokihanga i a Oxford ka haramai ia ki Aotearoa mai i Ahitereiria i eetahi waa. Tino pai ki te kite i a ia. He hoa rawe a Rawiri.

As for Dave he carried on with his sports and studies and went back to Australia from Oxford. He comes to New Zealand sometimes. A great mate.

I tooku hokihanga mai ki a a Aotearoa, i te otinga o taku mahi taakuta ka miharo au i te rahi o ngaa taangata i moohio ai moo too maatou haerehanga ki a Hiruhaarama. Kua koorero a John moo teeraa ki teenaa wharenui, teenaa hoki ki te Urewera me eetahi waahi hoki.

When I got back to New Zealand having finished my doctorate I could not believe how many people knew the story of our trip to Jerusalem. John had told it again and again in meeting houses in the Urewera and elsewhere.

I eetahi waa ka takoto au i tooku moenga i ngaa poo, aa, ka ruu kee tooku tinana i te kata i a au e whakaaro ana moo too maatou haerenga ki a Hiruhaarama. Too maatou tino koa hoki! Ki tooku hinengaro i teenaa waa o tona oranga ka noho a Hoani i waenganui i eetahi taangata taumaha, aa, he tuuranga toona $\mathrm{i}$ te marea o Aotearoa, ki te Ao Maori, ki waenganui hoki i a Tuuhoe, aa, naa eenei mea ka hari ia i eetahi mea taumaha, he taumaha rawa pea. I too maatou haerenga ka watea a John ki te koorero, ki te kata hoki, kia hoki ai ia ki ngaa waa pai ki Te Hokowhitu a $\mathrm{Tu}$, aa, kia whakangahau noa iho.

Every so often I lie in bed at night and start shaking with laughter, thinking about our trip to Jerusalem. We had such 
fun. I think that at that time of his life John was used to being surrounded by serious people and had a position in New Zealand society, in Maoridom and amongst the Tuhoe that meant that he carried a lot of weight, it was all pretty heavy. On the trip he was free to talk and laugh and go back to the wild old days in the Maori Battalion and just generally yahoo around.

Engari kau raa he waa taumaha hoki teenaa. Teeraa pea he waa maana e tuku iho i eetahi mea. He rahi kee o nga mea moo John Rangihau i teenaa waa i paa ai ki te rangatiratanga Maori, aa, ka koorero ia i nga waa katoa moo ngaa aahua pai o te rangatiratanga. I runga o teenaa whakaaro ko te koorero moo Colonel Pita Awatere raatou ko Bob Mahuta ko Hugh Kawaharu me eenaa moumou aahua he mea $i$ haangai raa eenei mea $i$ whakakoikoi hoki ki te kaupapa o rangatiratanga i toona anoo naa hinengaro.

But it was a serious time as well. It may be that he got a lot out of his system. A lot of John Rangihau at that time was to do with Maori leadership and he was always thinking about the best styles of leadership. So all the talk about Colonel Peter Awatere, about Hugh Kawharu, Bob Mahuta and other leaders of the day was a kind of processing, a working out of what he thought.

Teeraa pea e tika ana kia whakaarongia ai he waa ki mua, he waa ki muri hoki. I mua i te haerenga ko oona tino whakaaro ko ngaa mea peenaa i te kawa o te marae me te Ahurei o Tuhoe. Ki muri o te haerenga ha haere tonu ia moo eenei mea aa, he kitenga hoki noona i toro atu ai ki a Puu Ao Te Ata Tuu, he mahere hapori kua tipu ake i te whakatakotoranga o teenaa naa John maa ki 1989.

There may even have been a Before and an After. Before the trip John was into things like the Tuhoe Festival and the te kawa o te marae. After the trip he carried on with those things and also had a vision that extended to, eventually, Pu-Ao-TeAta-Tu, a social work manifesto that has endured and grown in significance since John and others put it together in 1989. 
Teeraa pea ka rere teetahi mea ki teetahi. Teeraa pea kaaore kau he mea nui i waaenganui i te Mua me te Muri. Teeraa pea he waa pai noa iho toona i te haerenga ki a Hiruharama.

Or maybe one thing just led to another in John's life. Perhaps it was not really a matter of Before and After. Perhaps he just had a good time on the trip to Jerusalem.

Ki tooku whakaaro ko John Rangihau, peeraa i eetahi atu mea e haere ana ki te Whenua Tapu, he rahi kee oona anoo raa whakaaro moo toona whakapono, ki a ia tonu ko teenaa ko te Ringatuu.

I do think that John Rangihau, like many people who go to the Holy Land, had thought a lot about the basis of his faith, in his case the Ringatu.

Ko au, kua hoki au ki a Hiruhaarama. I te tau 1999 ka haere au ki reira ki teetahi huinga toko i te ora. I teenaa wa ka mahi au ki te Whare Waananga o Wikitoria i teetahi Wahanga $\mathrm{i}$ whakakoingia mai e Hoani Rangihau. Ka manaaki a Alon Kadish me toona hoa wahine i a au, aa, ka noho au ki runga o te Via Dolorosa. He rahi ngaa whakaaro, nga paatai hoki moo too maatou haerenga ki a Hiruhaarama o mua.

As for me I went back to Jertusalem. I 1999 I was there for a social work conference. By this time I was working for Victoria University in a Department that John Rangihau had helped to define. Alon Kadish, now a University Lecturer at the Hebrew University, and his partner looked after me. I stayed above the Via Dolorosa. I had plenty of thoughts and questions about our earlier trip to Jerusalem.

\section{He whakaaro whakatepe}

Kaore kau he paatai, ko Hiruhaarama, ki a au, he huarahi $\mathrm{i}$ taea te nuku peenaa i toku whakawhiti i te huarahi ki Ramarama mai i tooku waahi taapere i raro raakau ki a Tipene Kura, te haerenga ki tua o ngaa moana i Aotearoa ki a Oxford raanei.

There is no question that Jerusalem, for me, was a road crossed, like crossing the road at Bombay from my outdoor 
theatre to St Stephens or crossing from the New Zealand academic context to Oxford.

Mai raano kua whakaaro au moo ngaa waahi wheenaa i a Roma, i a Atena, Hiruhaarama, aa, wheenaa i a Raanana, Paris me New York mai i teetahi waahi moemoea, mai i te pakiwaitara taawhiti, mai i a nehe tonu pea. Ki a au, mai i a Manurewa ki te ao hou, he taawhiti rawa atu te haere whakaaro, aa. ko eenei waahi, mai i te wao moemoea eenei.

All my life I'd thought about places like Rome, Athens, Jerusalem and like London, Paris and New York these were from a dreamscape from a myth that was a long long way and as long ago from Manurewa, New Zealand in the New World as you could get.

Ki a Hoani, mai i a Waikaremoana he haangai, hookai raanei i teenaa wao ki teenaa mai i te Haahi Ringatuu me oona aahua ki te Urewera ki a Hiruhaarama ki te whenua o ngaa Iharaira.

To John, coming from Waikaremoana there was a crossing of dimensions that involved, I guess, the Ringatu Church, the way that the Prebyterianism of the Urewera- the Reverend Laughton, Sister Annie, Laughton and and Rua (?)- treated Jerusalem and other things.

Ka haramai hoki a Hoani i te waa o Sinclair o te whakaaro mo te mana motuhake o te motu. He mea hou, i tatari te Dominion ki koonei moo teetahi waa roa rawa ki eetahi waahi, aa, ka pono tonu eetahi taangata i ngaa mea wheenaa raa i te Empire. Ka tuu ngaa taangata ki te whare pikitia moo te Kiingi, te Kuini raanei. He toa moo Nga Iharaira o Ingarangi ki te huarahi o Kuini ki Taamaki Maakau Rau.

John Rangihau came from the time of Sinclair, the time of nationalism in New Zealand. This was very new, the Dominion had lasted longer than elsewhere and people still believed in things like Empire. People stood in the theate for the Queen. The British Israelites had a store in Upper Queen Street.

Then of course there was Rua kenana and reference to Nga Iharaira in the Urewera... 
Kai koonei hoki te whakaaro moo Rua Kenana me te aronga ki Ngaa Iharaira ki te Urewera...

Ka haramai hoki a Hoani Rangihau i te waa o Martin Luther King. Mai hoki i te wa o te apartheid ki te tonga o Awherika me te moohio he hapa nui teenaa. Mai hoki ra i te waa o Wounded Knee. Mai hoki i toona waa mahi i te wao toko $i$ te ora i te Tari Maori me te rangatiratanga o toona naa iwi o Tuuhoe.

John Rangihau also came from the time, internationally, of Civil Rights, of Martin Luther King. And he came from the time of apartheid in South Africa being realised as seriously wrong. And from the time of Wounded Knee in the Americas. He also came from a life of social service, social work in the Department of Maori Affairs and leadership of his iwi, the Tuhoe.

Mai hoki i te waa o te whakahaapairanga o te reo me ngaa pukapuka peenaa i Te Rangatahi naa tona hoa a Hoani Waititi. He uaua moona inahoki ko te paatai ki a ia mai i a eetahi kia awhinatia te mahi whai anoo i ngaa tikanga me te reo ngaro. Engari ki a ia, mai i a Tuuhoe, kaaore anoo kia ngaro te reo me oona tikanga. Ka tata au ki teenaa inahoki ka ako au i te reo mai i ngaa taangata peenaa i a Pera Tahi kaaore kau raa kua ngaro too raatou reo.

And he came from a time of language nationalism if so it might be called. From the mid sixties and the time of Hoani Waititi's book, Te Rangatahi, John was caught up, as we all were in a reclamation process that was difficult for him in the sense that he was not actually reclaiming anything, simply speaking a language that he always had. This characterised my language learning as well. Never having formally studied Maori I picked it up from people like Pera Tahi who had always spoken it.

Kia whakatuungia a John hai taaonga o te motu, kaaore teenaa i teetahi mea whaitia ai e ia tonu. He wawata noona kia tuu ai ia hai rangatira moo toona anoo iwi, a Tuuhoe, aa, ko teenaa teenaa.

To be set up as a kind of linguistic and cultural treasure on a national basis was not something that I think John himself wanted. He certainly had an ambition to lead and speak for his 
iwi, Tuhoe but would always go back to that as something he was entitled to do and comfortable doing.

Ko toona mohio moo te kawa me te pai o taana korero ki runga marae, he mea whakamotuhake ia i eetahi taangata kia whakatuungia hokitia ia hai tauira.

There was also a coincidence of cultural craft and language in John's expertise in the kawa o te marae that set him apart just as it made him a role model.

Kia whakaarongia te waa ki a Oxford, e tika ana pea kia huri te waananga ki taana koha ki te mahi toko i te ora ki Aotearoa nei. He koha nui teenaa. e tika ana hoki kia whakaarongia toona kitenga o te ao $i$ te taha o Sinclair maa. Ka whai au i eenaa ira koorero i eetahi atu tuhinga ki eetahi tuhinga e whai mai ai.

To contextualise the period at Oxford at a later date study might be made of social work in Aotearoa something that John Rangihau made a very big mark in and one to which I also contributed. And also to comparison and contrast with other thinkers of nationalism and identity like Sinclair and others. In the next Monograph I attempt to capture what was for John, the developer of a specific form of social work that rested on his identity as a Tuhoe, his Tuhoetanga. 


\section{He rarangi pukapuka}

\section{Bibliography}

Cleave Peter 1973 Hatupatu and Kurangaituku in Ako (Ed. Volkerling M) Auckland Teachers Training College

1976 Wai Maori, Wai Tai 1976 Working Paper Maori Department University of Waikato

1983 Tribal and State like Political Formations in New Zealand Society. Journal of the Polynesian Society Volume 92 No.1

Greenwood, Janinka and Wilson, Arnold Manaaki 2006- Te Mauri Pakeaka, A Journey into the Third Space Auckland University Press

Lienhardt, Godfrey 1961, 1988 Divinity and Experience, The Religion of the Dinka Clarendon Press; New Ed edition (July 14, 1988)

Mataira, K, Pere R and Cleave P 1978 He Kupu Whakaahua Maaori, The Oxford Picture Dictionary of Maaori Oxford University Press

Ramsay, Peter D. K. 1975 The Family and the school in New Zealand society: An introduction to the sociology of New Zealand education Pitman Pacific

Volkerling M (ed) 1973 Ako Auckland Teachers Training College Waititi, Hoani, 1993 Te Rangatahi Legislation Direct 